\title{
Stratigraphy of the Koobi Fora Formation (Pliocene and Pleistocene) in the Loiyangalani region of northern Kenya
}

\author{
Patrick N. Gathogo ${ }^{\mathrm{a}}$, Francis H. Brown ${ }^{\mathrm{a}, *}$, Ian McDougall ${ }^{\mathrm{b}}$ \\ ${ }^{a}$ Department of Geology and Geophysics, University of Utah, 135 South 1460 E, Room 209, Salt Lake City, UT 84112, USA \\ ${ }^{\mathrm{b}}$ Research School of Earth Sciences, The Australian National University, Mills Road, Acton, Canberra, ACT 2601, Australia
}

Received 30 October 2007; received in revised form 17 January 2008; accepted 29 January 2008

Available online 20 February 2008

\begin{abstract}
Tuffaceous marker beds in the Loiyangalani region were previously identified as correlative with similar beds in the Shungura and Koobi Fora Formations of southwestern Ethiopia and northwestern Kenya. Associated sedimentary strata correlate with the Koobi Fora Formation, and include intercalated basalt flows. In the Loiyangalani region the Koobi Fora Formation has a composite thickness of at least $257 \mathrm{~m}$, and records one time interval for which no strata are known in the Koobi Fora region. Four members of the Koobi Fora Formation (Lonyumun, Tulu Bor, Burgi, and KBS) are recognized in the region, and a composite member (Moiti-Lokochot) proposed because the Lokochot Tuff, the formal boundary between the Moiti and Lokochot Members has not been identified. This extends the known geographic area of the Koobi Fora Formation $100 \mathrm{~km}$ southward. These strata, together with others, were previously termed 'Loiyangalani formation (or Formation)'. Deposition in the Loiyangalani region began at about the same time as in the Koobi Fora and Nachukui Formations. Newly named basalts are Kankam (3.2-3.3 Ma), Lenderit (2.02 to $2.18 \pm 0.02 \mathrm{Ma}$ ), and Balo (1.79 $\pm 0.02 \mathrm{Ma}$ ). We also report K/Ar ages on basalts from Mt. Kulal (2.04 \pm 0.02 to $2.40 \pm 0.03 \mathrm{Ma})$ east of the region and from Serima Gorge $(0.77 \pm 0.01 \mathrm{Ma})$ south of the study area.

(c) 2008 Elsevier Ltd. All rights reserved.
\end{abstract}

Keywords: Kenya; Turkana Basin; Omo Group; Koobi Fora Formation; Stratigraphy; Loiyangalani

\section{Introduction}

The Koobi Fora Formation northeast of Lake Turkana in northern Kenya is renowned for its prehistoric sites and comparatively complete stratigraphic Pliocene and Pleistocene sections. Detailed accounts of the stratigraphic record of the formation are available for the Ileret, Karari, Koobi Fora, and Allia Bay regions (Brown and Feibel, 1986, 1991; Gathogo and Brown, 2006), and the mammalian fossil record is described by Leakey and Leakey (1978), Harris (1983, 1991), Wood (1991), and Isaac and Isaac (1997). In this study we describe newly recognized sections of the for-

\footnotetext{
* Corresponding author. Tel.: +1 801581 8767; fax: +1 8015817065 .

E-mail addresses: Patrick.N.Gathogo@utah.edu (P.N. Gathogo), Frank.Brown@utah.edu (F.H. Brown), Ian.McDougall@anu.edu.au (I. McDougall).
}

mation and intercalated basalts in the Loiyangalani region southeast of Lake Turkana (Figs. 1 and 2).

Sedimentary and volcanic sequences of the Loiyangalani region discussed in this study were previously mapped and assigned pre-Pliocene ages by Ochieng' et al. (1988), Wilkinson (1988), and Rop (1990). Preliminary visits to the region, however, showed that the area preserves tuffaceous marker beds that lie within the Omo Group (de Heinzelin, 1983), a sedimentary sequence that crops out elsewhere in the Omo-Turkana Basin (southwestern Ethiopia and northwestern Kenya). Potassium-argon dates on basalts from the Loiyangalani region are of Pliocene age. Motivation for this study, therefore, commenced from the need to clarify inconsistencies about the geology of the region.

Potassium-argon ages reported here were obtained at the Research School of Earth Sciences, the Australian National University, using methods described in McDou- 


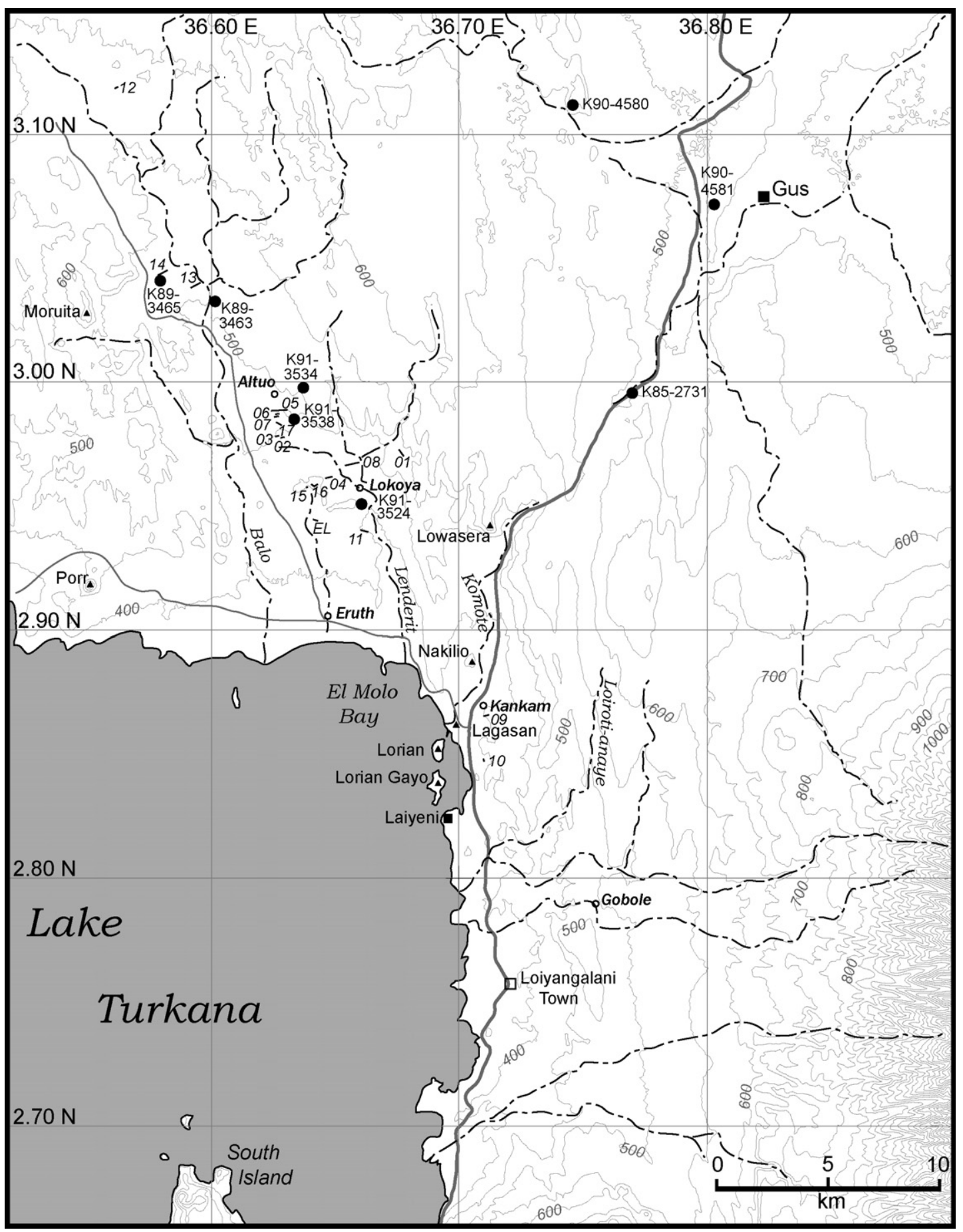

Fig. 1. Map of the Loiyangalani region with contours at $100 \mathrm{~m}$ intervals taken from the $90-\mathrm{m}$ USGS digital topographic dataset. Locations of dated samples are shown as filled circles with the sample number. Locations of measured sections are shown as short lines identified by the last two digits of the section number (of the form PNG-LY08) given in italics.

gall and Feibel (1999). Electron microprobe analyses on the glass phase of tuffs were obtained at the University of Utah following procedures described by Nash (1992), and using standards reported in Brown et al. (2006). Trace element analyses on the glass phase of tuffs were obtained by $\mathrm{X}$-ray fluorescence at the University of Utah following procedures described by Cerling and Brown (1982). For our discussion, we accept the age estimates of Gradstein et al.
(2004) for the Pliocene-Pleistocene boundary at $1.81 \mathrm{Ma}$, and the Pliocene-Miocene boundary at 5.33 Ma.

\subsection{Previous studies}

Hitherto the geology of the Loiyangalani region has been based on studies conducted at reconnaissance scale by Ochieng' et al. (1988), Wilkinson (1988), and Rop 


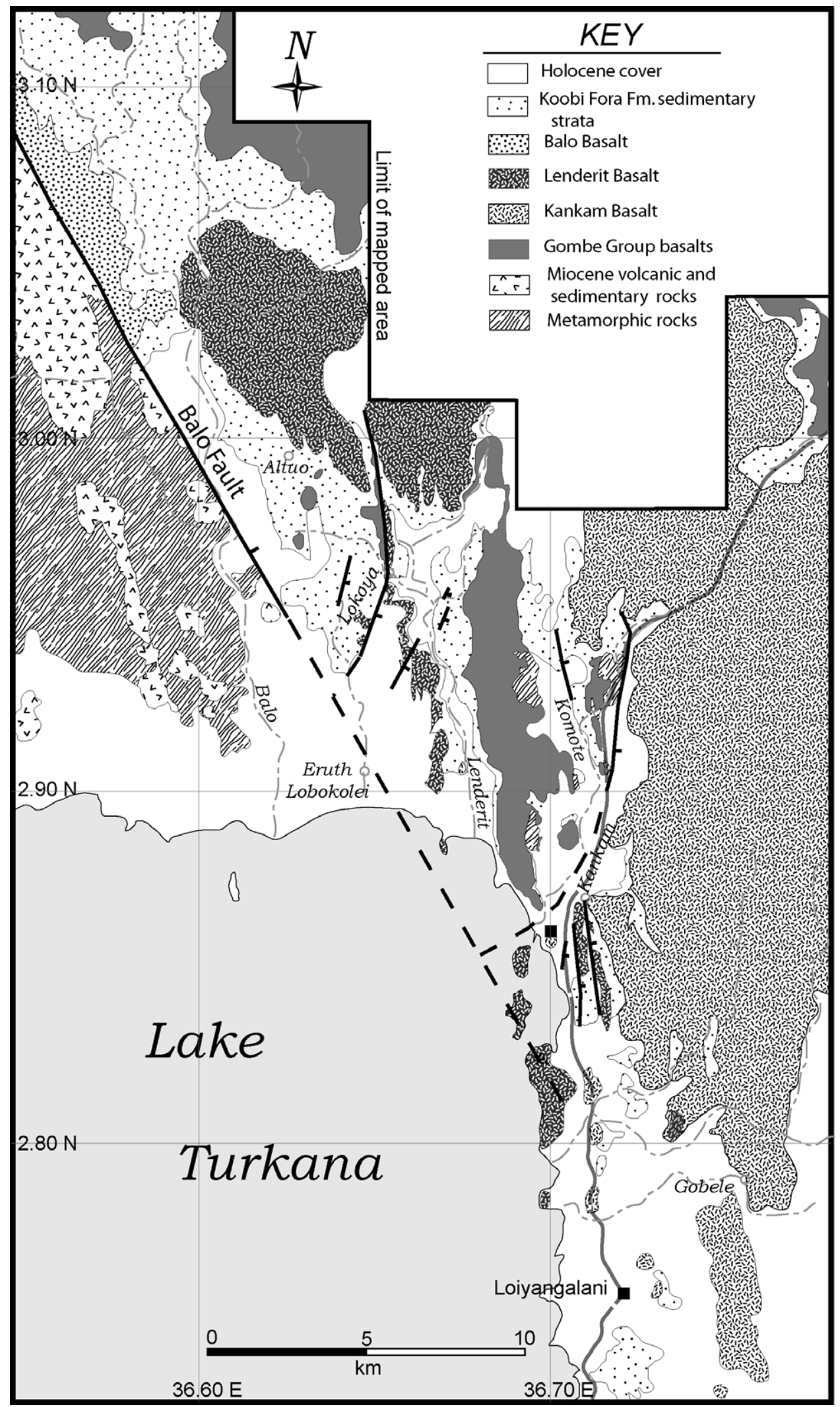

Fig. 2. Geological map of the Loiyangalani region. See Fig. 1 for sample locations and section locations.

(1990). Their published geologic maps (scale 1:250,000) show Neogene sedimentary and volcanic rocks as the dominant exposures, comprising nearly equal proportions of outcrop areas in the region. Metamorphic rocks regarded as being of late Proterozoic or early Phanerozoic age (Ochieng' et al., 1988) are also present, but they are exposed over 
Composite Column Named markers

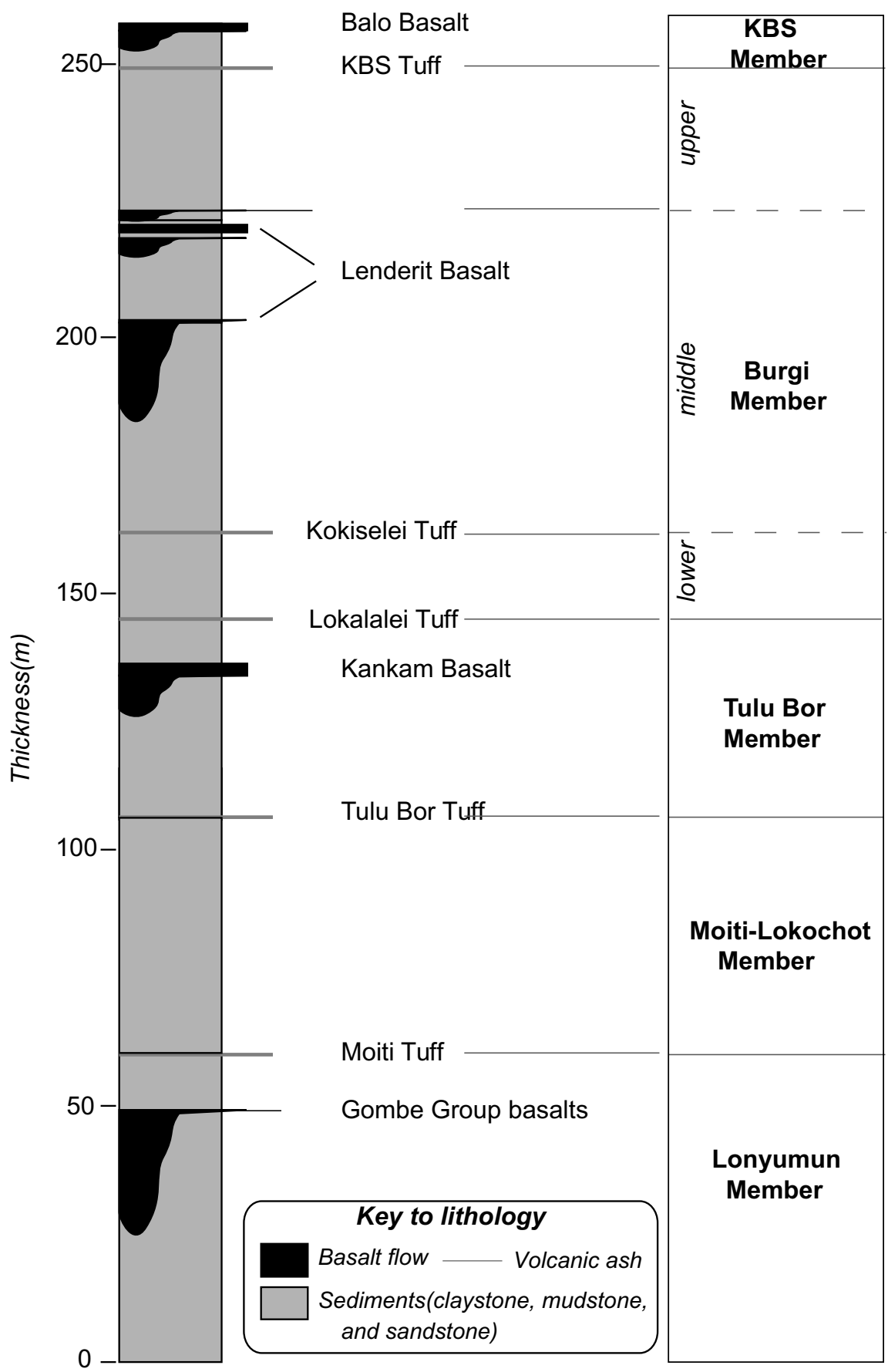

Koobi Fora Fm. Members

KBS

Member

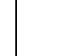


rocks exposed in the northern and southern parts of the region as one stratigraphic unit, the "Kajong Formation." Assignment of sedimentary strata in the region to preMiocene by Rop (1990) is based on his observations that these strata are overlain by "Loiyangalani Formation", and he notes that "recent $\mathrm{K}-\mathrm{Ar}$ dates in the base of the Loiyangalani Formation yield a date of $18.4 \pm 0.5$ m.y. (Fitch and Miller Associates, Cambridge, unpub. data)."

Virtually all volcanic rocks in the Loiyangalani region are mapped as plateau basalts and assigned a Pliocene age in the northern part of the region by Wilkinson (1988), but a Miocene age in the central and southern parts of the region by Ochieng' et al. (1988). In addition Ochieng' et al. (1988) mapped the two northern hills at El Molo Bay (islands during high lake levels) as Pliocene and Pleistocene volcanic breccia, and two igneous rock outcrops immediately northeast and southeast of the bay as dolerite plugs and sheets. Rop (1990) mapped all plateau basalts in the region as Miocene. A revised geological map of the region (Fig. 2) is based on work reported here and a summary of the stratigraphy is shown in Fig. 3.

\section{Koobi Fora Formation and Omo Group deposits}

Brown and Feibel (1986) formally defined the Koobi Fora Formation as "sedimentary strata of the Koobi Fora region of Pliocene and Pleistocene age that lie disconformably or unconformably on, or are in fault contact with, Miocene and Pliocene volcanic rocks and/or associated sediments, and are disconformably overlain by the late Pleistocene and Holocene Galana Boi Beds of Bowen and Vondra (1973)." They described the formation, which has a composite thickness of $565 \mathrm{~m}$, in terms of eight members, five of which are Pliocene (Lonyumun, $36.8 \mathrm{~m}$; Moiti, $59.9 \mathrm{~m}$; Lokochot, $34.4 \mathrm{~m}$; Tulu Bor, $86.2 \mathrm{~m}$; and Burgi $147 \mathrm{~m}$ ), and the remainder of which are Pleistocene (KBS, $136.3 \mathrm{~m}$; Okote, $21.6 \mathrm{~m}$; and Chari, $42.7 \mathrm{~m}$ ).

Member boundaries of the Koobi Fora Formation are based on tephra layers (Brown and Feibel, 1986), and in this study we extend the formation to the Loiyangalani region by identifying correlative tephra layers in local sections. Sedimentary features of Pliocene strata reported in this study show evidence of depositional integration with the Omo Group deposits recorded elsewhere in the Omo-Turkana Basin. For example, records of the perennial proto-Omo River in the Loiyangalani region are coeval with records in the Shungura Formation (Lower Omo Valley, Ethiopia; de Heinzelin, 1983), Nachukui Formation (West Turkana, Kenya; Harris et al., 1988) and in the Koobi Fora Formation elsewhere east of Lake Turkana (e.g., Ileret, eastern Karari, northern Koobi Fora, and Allia Bay regions).

\section{Stratigraphy}

The Koobi Fora Formation in the Loiyangalani region has a composite thickness of at least $257 \mathrm{~m}$ (Fig. 3), and is composed of sedimentary rocks with intercalated basalts.
Five members that constitute the Pliocene sequence of the formation have been identified, most outcrops of which occur in the central and western parts of the region. These Pliocene deposits are locally underlain by metamorphic rocks of presumed late Proterozoic and/or early Phanerozoic age, and are disconformably overlain by the Holocene Galana Boi Formation of Owen and Renaut (1986). In thickness and exposure Pliocene basalts dominate over sedimentary strata in the northern, eastern, and southern parts of the region. Reconnaissance work and satellite imagery suggest that these basalts also extend north and east beyond the region of study.

Strata of the Lonyumun, Tulu Bor, Burgi, and KBS members in the Loiyangalani region are identified and described under their corresponding formal names below. The remaining two Pliocene members, Moiti and Lokochot, cannot be differentiated as separate formal units because the base of the Lokochot Tuff, the formal boundary between the two members, has not been identified in the Loiyangalani region. Thus, using conventions set by the International Stratigraphic Code (Salvador, 1994) for naming of units with stratigraphic uncertainty, we provisionally adopt the name Moiti-Lokochot Member to refer to undifferentiated strata of the Moiti and Lokochot Members in the Loiyangalani region.

Pliocene basalts exposed in the Loiyangalani region described below have not been reported elsewhere in the Omo-Turkana Basin except for those of the Gombe Group ( 4.0 Ma: Haileab et al., 2004; see also Table 1), which crop out in many parts of the basin (Watkins, 1983; Key and Watkins, 1988; Wilkinson, 1988; Haileab et al., 2004). Further, no formal names exist for other Pliocene basalts in the region. For this reason formal names and definitions for these basalts, are presented below in description of the appropriate local stratigraphic sequences. All geographic locations in this study are given in terms of latitudes and longitudes that were collected and recorded using a hand-held GPS receiver with the datum set to WGS-84. All descriptions and member thicknesses given below refer to units exposed in the Loiyangalani region.

\subsection{Lonyumun Member}

Strata of the Lonyumun Member are at least $60 \mathrm{~m}$ thick. Basal deposits of this member overlie metamorphic rocks near Lowasera (Fig. 4), but no underlying (Miocene or older) sedimentary or volcanic rocks were identified. The thickest continuous section of the member is PNG-LY05 (Fig. 5), which is exposed south of Altuo water hole in the northwestern branch of the Lenderit drainage (Fig. 1).

The first unit in section PNG-LY05 is a pale yellowto-orange sandstone $(18 \mathrm{~m})$ that is rich in clay and silt, with a calcite-cemented interval $4.5 \mathrm{~m}$ above the base and basalt dikes $12 \mathrm{~m}$ above the base and at the top. Next in sequence is a medium- to coarse-grained sandstone $(6 \mathrm{~m})$ cemented with calcite, locally stained red, brown, grey, and black by ancient hydrothermal fluids and by baking 
Table 1

Representative analyses of glass from tuffs in the Koobi Fora Formation of the Loiyangalani region

\begin{tabular}{|c|c|c|c|c|c|c|c|c|c|c|c|c|c|c|c|c|c|c|c|c|c|c|}
\hline & $\mathrm{N}$ & $\mathrm{SiO}_{2}$ & $\mathrm{TiO}_{2}$ & $\mathrm{Al}_{2} \mathrm{O}_{3}$ & $\mathrm{Fe}_{2} \mathrm{O}_{3}{ }^{\mathrm{a}}$ & $\mathrm{MnO}$ & $\mathrm{MgO}$ & $\mathrm{CaO}$ & $\mathrm{Na}_{2} \mathrm{O}$ & $\mathrm{K}_{2} \mathrm{O}$ & $\mathrm{Cl}$ & Sum & $\begin{array}{l}\text { Less } \mathrm{O} \\
\text { for } \mathrm{Cl}\end{array}$ & $\mathrm{H}_{2} \mathrm{O}$ & Total & $\mathrm{Ba}$ & $\mathrm{Nb}$ & $\mathrm{Rb}$ & $\mathrm{Sr}$ & $\mathrm{Y}$ & $\mathrm{Zn}$ & $\mathrm{Zr}$ \\
\hline \multicolumn{23}{|l|}{ Moiti Tuff } \\
\hline ТВ04-058 & 17 & 75.10 & 0.19 & 10.95 & 2.68 & 0.08 & 0.01 & 0.21 & 2.68 & 4.15 & 0.11 & 96.16 & 0.02 & 5.47 & 101.61 & & & & & & & \\
\hline K93-6039 & 16 & 75.48 & 0.17 & 11.13 & 2.64 & 0.09 & 0.01 & 0.20 & 2.85 & 3.84 & 0.11 & 96.53 & 0.02 & 4.53 & 101.04 & 398 & 105 & 76 & 11 & 103 & 204 & 982 \\
\hline K93-6040 & 13 & 75.35 & 0.16 & 11.00 & 2.63 & 0.08 & 0.01 & 0.21 & 3.09 & 4.02 & 0.11 & 96.66 & 0.02 & 4.50 & 101.14 & 388 & 112 & 84 & 5 & 105 & 206 & 1014 \\
\hline \multicolumn{23}{|l|}{$\alpha$-Tulu Bor } \\
\hline ТВ04-021 & 20 & 72.34 & 0.21 & 12.58 & 1.39 & 0.04 & 0.12 & 0.52 & 2.76 & 5.07 & 0.09 & 95.13 & 0.02 & 6.42 & 101.52 & & & & & & & \\
\hline ТВ04-030 & 21 & 72.50 & 0.21 & 12.60 & 1.37 & 0.04 & 0.12 & 0.50 & 2.97 & 5.18 & 0.09 & 95.58 & 0.02 & 6.01 & 101.57 & & & & & & & \\
\hline ТВ04-052 & 14 & 73.47 & 0.21 & 12.70 & 1.35 & 0.04 & 0.11 & 0.49 & 2.79 & 3.96 & 0.09 & 95.22 & 0.02 & 6.01 & 101.21 & & & & & & & \\
\hline ТВ04-052 & 3 & 73.03 & 0.27 & 13.02 & 1.61 & 0.05 & 0.14 & 0.64 & 3.11 & 4.20 & 0.08 & 96.14 & 0.02 & 5.45 & 101.57 & & & & & & & \\
\hline K91-3521 & 15 & 73.89 & 0.20 & 13.11 & 1.39 & 0.04 & 0.12 & 0.50 & 3.63 & 3.67 & 0.08 & 96.63 & 0.02 & 4.51 & 101.12 & 337 & 69 & 111 & 32 & 50 & 53 & 287 \\
\hline K89-3470 & 18 & 72.62 & 0.20 & 12.71 & 1.39 & 0.05 & 0.12 & 0.52 & 3.32 & 3.85 & 0.09 & 94.86 & 0.02 & 5.67 & 100.51 & 498 & 74 & 115 & 39 & 53 & 97 & 342 \\
\hline \multicolumn{23}{|l|}{ Lokoya Tuff } \\
\hline K90-4612 & 10 & 46.64 & 2.61 & 15.99 & 12.46 & 0.20 & 5.50 & 10.58 & 3.39 & 1.31 & 0.04 & 98.73 & 0.01 & -0.24 & 98.48 & & & & & & & \\
\hline \multicolumn{23}{|l|}{$\beta$-Tulu Bor } \\
\hline ТВ04-080 & 12 & 74.17 & 0.13 & 12.17 & 1.60 & 0.06 & 0.05 & 0.30 & 3.22 & 4.79 & 0.09 & 96.59 & 0.02 & n.d. & 96.57 & & & & & & & \\
\hline K91-3523 & 10 & 74.86 & 0.13 & 12.54 & 1.51 & 0.05 & 0.06 & 0.29 & 3.73 & 3.84 & 0.09 & 97.10 & 0.02 & 3.88 & 100.96 & 199 & 86 & 116 & 14 & 61 & 77 & 372 \\
\hline K91-3523 & 4 & 73.17 & 0.25 & 12.89 & 1.46 & 0.04 & 0.14 & 0.53 & 3.19 & 3.16 & 0.08 & 94.92 & 0.02 & 5.66 & 100.56 & & & & & & & \\
\hline \multicolumn{23}{|l|}{ Unnamed Tuff } \\
\hline ТВ04-066 & 11 & 68.72 & 0.48 & 11.44 & 5.86 & 0.13 & 0.12 & 0.61 & 1.53 & 2.94 & 0.27 & 92.11 & 0.06 & 8.20 & 100.25 & & & & & & & \\
\hline K91-3537 & 12 & 67.17 & 0.42 & 11.22 & 6.01 & 0.14 & 0.12 & 0.57 & 0.42 & 2.22 & 0.28 & 88.57 & 0.06 & 10.26 & 98.77 & 404 & 153 & 112 & 196 & 92 & 156 & 970 \\
\hline \multicolumn{23}{|l|}{ Lokalalei Tuff } \\
\hline \multicolumn{23}{|l|}{ Mode 1} \\
\hline ТВ04-073 & 8 & 74.47 & 0.20 & 10.58 & 3.31 & 0.17 & 0.05 & 0.13 & 3.75 & 3.37 & 0.21 & 96.24 & 0.05 & 4.96 & 101.15 & & & & & & & \\
\hline ТВ04-074 & 7 & 71.32 & 0.18 & 10.18 & 3.33 & 0.15 & 0.04 & 0.13 & 4.40 & 3.13 & 0.21 & 93.07 & 0.05 & n.d. & 93.02 & & & & & & & \\
\hline ТВ04-075 & 7 & 74.19 & 0.20 & 10.56 & 3.37 & 0.17 & 0.05 & 0.13 & 3.60 & 3.37 & 0.21 & 95.83 & 0.05 & 4.98 & 100.76 & & & & & & & \\
\hline K93-6054 & 10 & 75.08 & 0.18 & 10.64 & 3.30 & 0.16 & 0.05 & 0.13 & 3.55 & 3.05 & 0.20 & 96.36 & 0.05 & 4.40 & 100.71 & 118 & 128 & 112 & 5 & 71 & 134 & 951 \\
\hline K93-6050A & 18 & 75.56 & 0.18 & 10.91 & 3.27 & 0.16 & 0.05 & 0.12 & 4.46 & 4.24 & 0.21 & 99.16 & 0.05 & 1.40 & 100.51 & 1 & 168 & 170 & 0 & 88 & 164 & 1323 \\
\hline \multicolumn{23}{|l|}{ Mode 2} \\
\hline ТВ04-073 & 4 & 71.40 & 0.34 & 12.89 & 2.88 & 0.12 & 0.16 & 0.24 & 4.40 & 3.68 & 0.13 & 96.24 & 0.03 & 5.21 & 101.42 & & & & & & & \\
\hline ТВ04-075 & 8 & 70.82 & 0.34 & 13.20 & 2.81 & 0.12 & 0.19 & 0.24 & 3.92 & 3.60 & 0.12 & 95.35 & 0.03 & 5.63 & 100.95 & & & & & & & \\
\hline \multicolumn{23}{|l|}{ Mode 3} \\
\hline ТВ04-073 & 4 & 69.72 & 0.46 & 14.11 & 2.68 & 0.14 & 0.25 & 0.33 & 4.62 & 4.24 & 0.11 & 96.67 & 0.02 & 5.16 & 101.81 & & & & & & & \\
\hline K93-6054 & 3 & 70.07 & 0.45 & 14.47 & 2.76 & 0.13 & 0.28 & 0.38 & 4.28 & 3.73 & 0.08 & 96.64 & 0.02 & 4.54 & 101.16 & & & & & & & \\
\hline K93-6050B & 14 & 70.52 & 0.46 & 14.59 & 2.68 & 0.11 & 0.27 & 0.34 & 4.85 & 4.55 & 0.09 & 98.46 & 0.02 & 3.02 & 101.46 & 19 & 96 & 89 & 0 & 57 & 108 & 681 \\
\hline K93-6049 & & & & & & & & & & & & & & & & 101 & 131 & 116 & 2 & 74 & 132 & 985 \\
\hline \multicolumn{23}{|l|}{ Kokiselei Tuff } \\
\hline ТВ04-039 & 9 & 72.51 & 0.42 & 9.01 & 5.80 & 0.29 & 0.10 & 0.20 & 1.04 & 2.21 & 0.17 & 91.76 & 0.04 & 8.13 & 99.85 & & & & & & & \\
\hline ТВ04-067 & 13 & 68.98 & 0.41 & 8.65 & 5.99 & 0.28 & 0.10 & 0.19 & 2.56 & 2.30 & 0.17 & 89.63 & 0.04 & n.d. & 89.59 & & & & & & & \\
\hline ТВ04-077 & 15 & 73.21 & 0.36 & 8.94 & 6.02 & 0.28 & 0.10 & 0.20 & 1.95 & 2.26 & 0.18 & 93.51 & 0.04 & n.d. & 93.47 & & & & & & & \\
\hline K90-4607 & 16 & 72.39 & 0.35 & 9.10 & 5.68 & 0.26 & 0.10 & 0.18 & 2.00 & 2.95 & 0.16 & 93.18 & 0.04 & 7.00 & 100.14 & 29 & 163 & 103 & 3 & 122 & 260 & 1276 \\
\hline K91-3525 & 15 & 73.33 & 0.38 & 9.36 & 5.77 & 0.25 & 0.10 & 0.19 & 1.65 & 1.84 & 0.16 & 93.04 & 0.04 & 7.02 & 100.02 & 82 & 152 & 94 & 4 & 111 & 212 & 1214 \\
\hline K93-6053 & 12 & 73.10 & 0.36 & 9.06 & 5.88 & 0.28 & 0.10 & 0.19 & 2.18 & 2.30 & 0.18 & 93.62 & 0.04 & 6.17 & 99.75 & 47 & 131 & 80 & 7 & 98 & 221 & 1049 \\
\hline \multicolumn{23}{|l|}{ Egales Tuff } \\
\hline K90-4608 & 16 & 62.89 & 0.70 & 16.22 & 4.88 & 0.25 & 0.55 & 0.79 & 1.94 & 2.77 & 0.26 & 91.24 & 0.06 & 8.56 & 99.74 & 668 & 182 & 87 & 11 & 53 & 134 & 763 \\
\hline K07-470 & 17 & 61.64 & 0.73 & 15.59 & 4.87 & 0.25 & 0.53 & 0.77 & 3.56 & 4.16 & 0.26 & 92.91 & 0.06 & 7.93 & 100.78 & & & & & & & \\
\hline \multicolumn{23}{|l|}{ KBS Tuff } \\
\hline K89-3464 & 1 & 73.51 & 0.18 & 10.49 & 3.02 & 0.11 & 0.02 & 0.18 & 2.13 & 1.39 & 0.18 & 91.22 & 0.04 & 6.41 & 97.59 & 40 & 190 & 163 & 3 & 123 & 243 & 1195 \\
\hline K90-4593 & 19 & 74.01 & 0.17 & 10.81 & 2.86 & 0.12 & 0.04 & 0.18 & 3.66 & 4.36 & 0.19 & 96.39 & 0.04 & 4.70 & 101.05 & 1 & 183 & 153 & 4 & 117 & 207 & 1164 \\
\hline
\end{tabular}

${ }^{\text {a }}$ All iron reported as $\mathrm{Fe}_{2} \mathrm{O}_{3}$. 


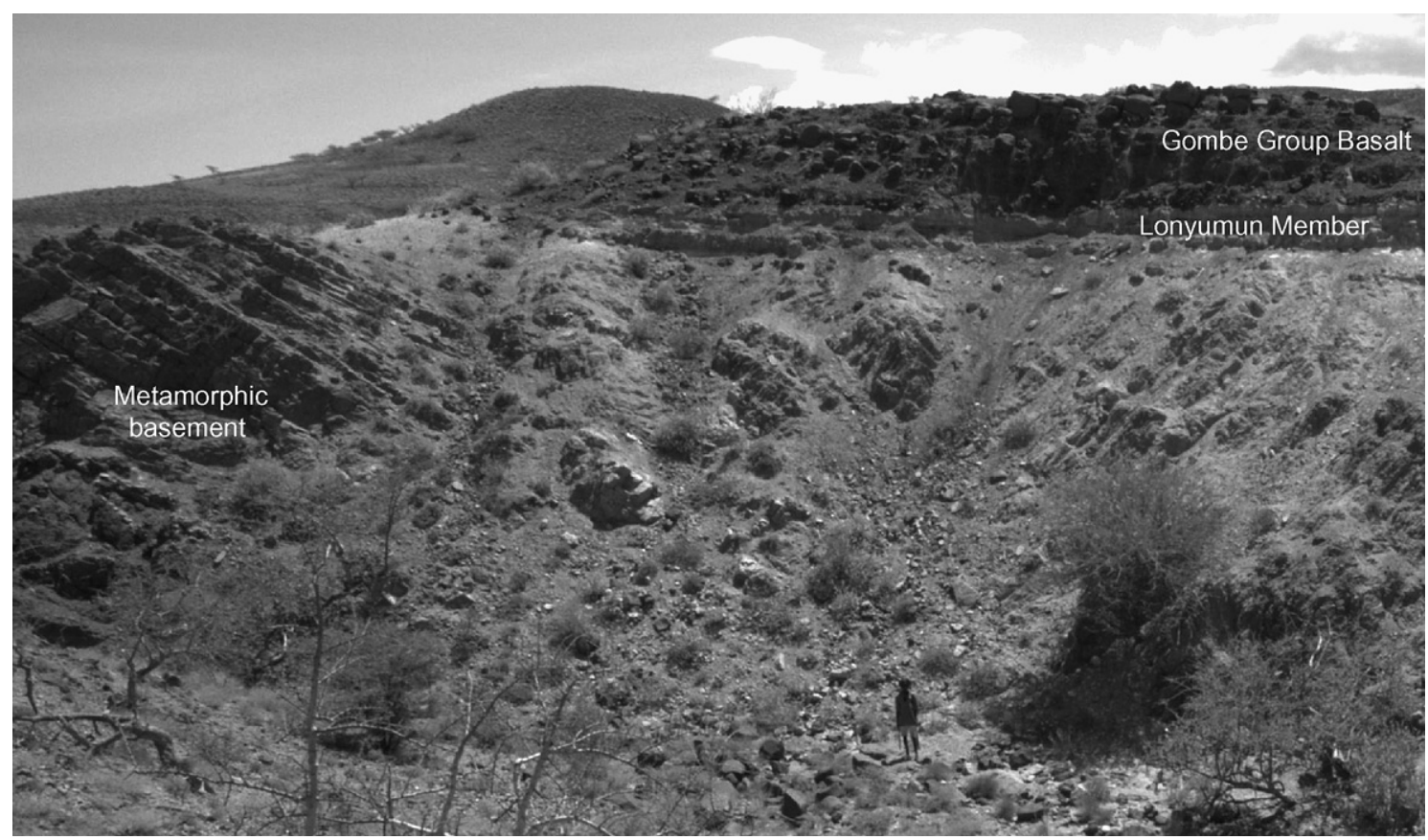

Fig. 4. Image of Lonyumun Member strata and Gombe Group Basalt resting on metamorphic basement rocks northwest of Lowasera; view to northwest.

\section{Lonyumun Member}

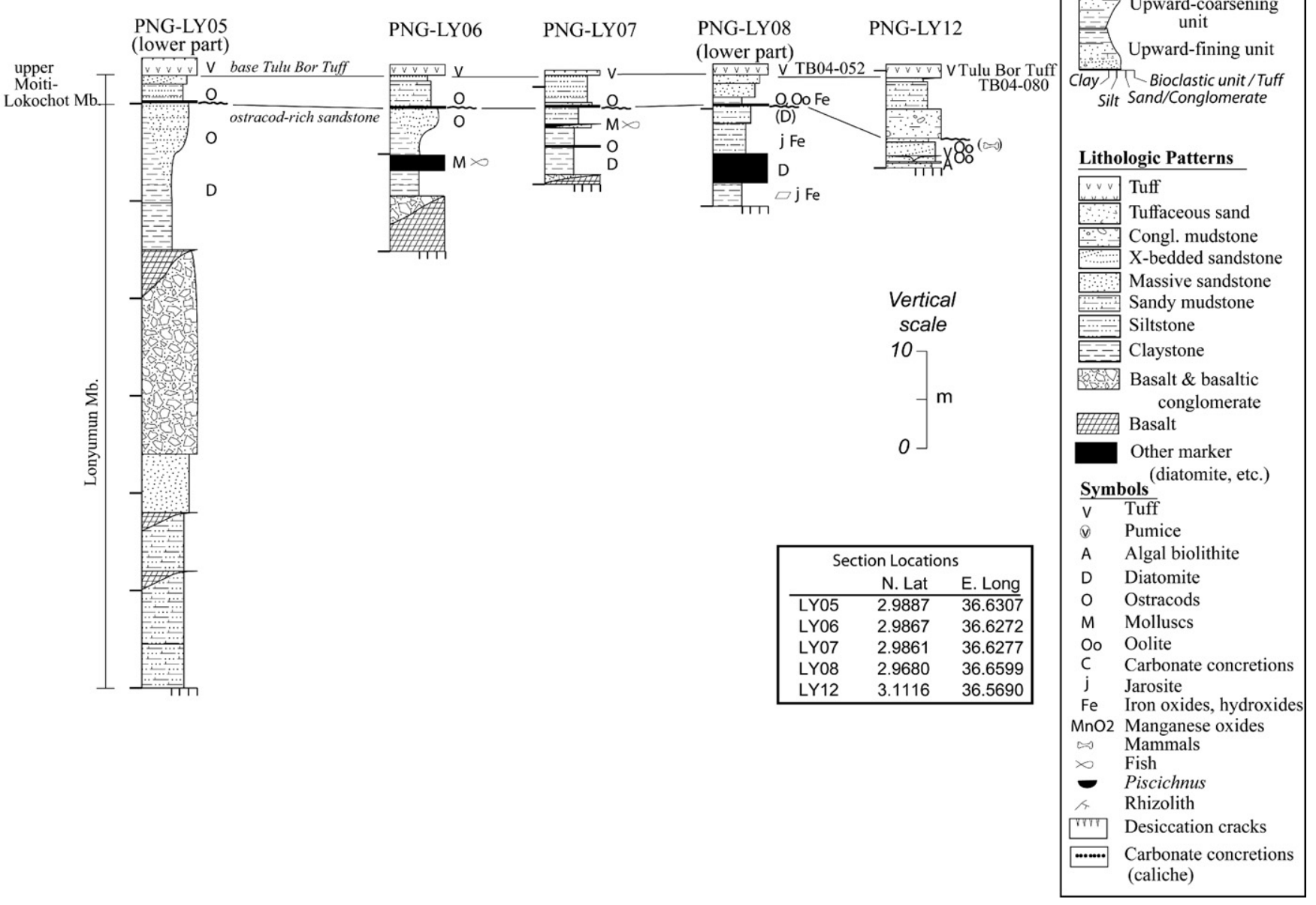

Fig. 5. Sections illustrating the stratigraphy of the Lonyumun Member of the Koobi Fora Formation in the Loiyangalani region. Section locations are shown in Fig. 1. 
along contacts with intrusive volcanic rocks. This second unit from the base of the section locally fills depressions eroded into the underlying sandstones. The third unit is an extremely weathered basalt $(21 \mathrm{~m})$, laterally associated with pebble and boulder conglomerates with clasts derived from basaltic agglomerates and dikes. An olive claystone $(4.8 \mathrm{~m})$ overlies the basaltic unit. The olive claystone is succeeded by an upward-coarsening sequence $(\sim 10 \mathrm{~m})$ that begins as a diatomaceous claystone and grades to an ostracod-rich sandstone. We adopt the base of a thin ostracodpacked sandstone $(10-20 \mathrm{~cm}$ ) (section PNG-LY05) as the local top of the Lonyumun Member because the Moiti Tuff (3.97 $\pm 0.03 \mathrm{Ma}$; McDougall and Brown, 2008) is absent in this section.

Local lithologic variations in the Lonyumun Member are significantly related to the absence or presence of basalt intrusions similar to those in section PNG-LY05. Near Altuo three sections (PNG-LY05, PNG-LY06, and PNGLY07; Fig. 5) that were measured $<200 \mathrm{~m}$ apart illustrate well the lateral variations that result from synsedimentary basaltic intrusions. The southern sections, PNG-LY06 and PNG-LY07, are $<50 \mathrm{~m}$ apart and are located proximal to an ancient eruptive center of the Gombe Group basalts. We give a detailed description of section PNG-LY06 for comparison with section PNG-LY05, located farther from the ancient eruptive center.

At the base of section PNG-LY06 a unit at least $5.7 \mathrm{~m}$ thick is composed of basalt dikes, and pebbles and boulders from an extremely weathered intrusive basalt. Overlying the basaltic unit is a thinly bedded to laminated olive claystone $(2.6 \mathrm{~m})$. Locally at the base of the claystone is a volcanic pebble conglomerate $(<20 \mathrm{~cm})$ with basalt clasts with surficial limonite stains. The claystone is sandier in the upper part than in the lower part, and it is overlain by a gastropod-packed sandstone $(1.6 \mathrm{~m})$ along a sharp contact. Bellamya (or perhaps Kaya) is the dominant gastropod in the sandstone, whereas Cleopatra is sparse. Locally the sandstones contain postcranial bones and teeth of fish, and lithic clasts include sparse basalt pebbles and redstained pyroclastic granules. Characteristic sedimentary structures of the sandstone unit are large-scale cross-beds that dip north and west. The sandstone is overlain by an upward-coarsening sequence $(5 \mathrm{~m})$ that begins as an olive claystone and ends as a pale olive coarse sandstone rich in ostracods. An ostracod-packed sandstone $(10-15 \mathrm{~cm})$ correlated with the marker bed at the top of the member in section PNG-LY05 caps the Lonyumun Member in this section.

A second significant local lithologic variant of the Lonyumun Member is a sequence with stromatolites that lies stratigraphically between Gombe Group basalt intrusions and the diatomaceous olive claystone discussed above. The stromatolites are identified at two locations, one south of Altuo water hole (at $2.9718^{\circ} \mathrm{N}, 36.6282^{\circ} \mathrm{E}$ ) and another in section PNG-LY12 (Fig. 5), well to the northwest of the mapped area. In the former location the olive claystone is very thin $(<0.5 \mathrm{~m})$, and it is absent at the latter. The description of the Lonyumun Member below (section PNG-LY12) further emphasizes local lithologic variations in this member.

Section PNG-LY12 begins with Gombe Group basalts overlain by a $50 \mathrm{~cm}$ thick, well-cemented sandstone with rounded quartz grains. Above the sandstone lies a matrix-supported conglomerate $(15 \mathrm{~cm}$ thick) composed of discoid basalt clasts encrusted with solitary stromatolites (up to $40 \mathrm{~cm}$ across). A pale gray oolitic sandstone $(60 \mathrm{~cm}$ ) with foreset crossbedding lies above the conglomerate, and contains elongate silt pebbles and a coarse-grained, dark brown basaltic tuff in its middle part. Next in section is a second pale gray oolitic sandstone $(1.5 \mathrm{~m})$ that contains sparse but well-preserved crocodilian postcranial elements. A very pale gray fine sandstone $(0.4 \mathrm{~m})$ that is rich in pyroxene follows, and this sandstone is truncated by a basalt pebble conglomerate $(3 \mathrm{~m})$ along an unconformity. The base of the conglomerate is adopted as the provisional top of the Lonyumun Member at this location because it is the most prominent indicator of a major unconformity that separates the Lonyumun and the Tulu Bor Members at many localities. Basalt pebbles locally make up a thin matrix-supported conglomerate in strata between the basaltic (Gombe Group) intrusion in the Lonyumun Member and the base of the Tulu Bor Member at many locations in the eastern part of the Lenderit drainage.

Diatomaceous olive claystones correlative with those overlying Gombe Group basalts in sections PNG-LY05 and PNG-LY06 attain maximum thickness within the Lenderit drainage where Gombe Group basalts are very thin or absent. Gypsum and jarosite are present within claystones of the Lonyumun Member, as is commonly the case elsewhere within the basin. Cerling (1977) suggests that these minerals form from oxidation of pyrite within the claystones. Within the olive claystone along the eastern margin of the drainage is a thin bed $(10-20 \mathrm{~cm})$ of airfall Moiti Muff (TB04-058, Table 1). A basaltic tuff with the same physical appearance (dark brown and coarse-grained) as the basaltic tuff in section PNG-LY12 occurs at an isolated outcrop of the Lonyumun Member northeast of Lowasera and along the road to Gus and Koobi Fora. There the basaltic tuff lies stratigraphically between Gombe Group basalts and diatomaceous olive claystones of the Lonyumun Member.

Gombe Group basalts in the region show a synchronogenic relationship where at least two flows occur either in contact with one another or with thin sedimentary sequences between them. The component basalt flows are identical (aphanitic) in hand specimen except at a few localities where basalts with pyroxene phenocrysts are associated (overlying, underlying, or dikes) with the aphanitic ones. Such a relationship is also commonly seen in Gombe Group basalts in the Ileret region and west of Lake Turkana.

Gombe Group basalts are medium grained $(0.1-0.2$ $\mathrm{mm})$, and composed of plagioclase $(\sim 50 \%)$, clinopyroxene $(\sim 20 \%)$, glass $(\sim 20 \%)$, and Fe-Ti oxides. Most are aphyric, but some samples have sparse phenocrysts of plagioclase, and clinopyroxene. Subhedral to euhedral plagioclase up 
to $1 \mathrm{~mm}$ in length forms a medium-grained matrix of interlocking laths; zoning, where present, is normal. Clinopyroxenes up to $0.5 \mathrm{~mm}$ across are euhedral to subhedral. Interstitial glass is gray, dark brown, or light purplish brown, commonly filled with oxide dendrites. The glass is either fresh and isotropic, or altered to chlorite.

\subsection{Moiti-Lokochot Member}

Strata between the Lonyumun and Tulu Bor Members in the Loiyangalani region could not be subdivided because neither the Lokochot Tuff (3.60 Ma, deMenocal and Brown, 1999; McDougall and Brown, 2008) nor any other appropriate stratigraphic marker occurs within this sequence. These strata, henceforth the Moiti-Lokochot Member, have a composite thickness about $45 \mathrm{~m}$. In the following paragraphs the Moiti-Lokochot Member is described as two discrete stratigraphic intervals: a lower interval $(0-39 \mathrm{~m})$ composed of strata - commonly with the Moiti Tuff at the base, and an upper interval (0-6.2 $\mathrm{m})$ whose strata are overlain by the Tulu Bor Tuff (3.43 \pm $0.03 \mathrm{Ma}$, Walter and Aronson, 1993; $3.438 \pm 0.023 \mathrm{Ma}$, McDougall and Brown, 2008).

The lower interval of the Moiti-Lokochot Member crops out only in the northeastern part of the Lenderit drainage east of Lokoya water hole. The base of the Moiti Tuff is the formal boundary between the Lonyumun and the Moiti members in their type sections (Brown and Feibel, 1986). Locally this tuff has been identified only within one kilometer of section PNG-LY01 (Fig. 6). Section PNG-LY01 records the most complete sequence of the upper interval of the Moiti-Lokochot Member as well as the entire member within the region. In the following descriptions strata of the lower interval are thus given more emphasis than those of the upper interval, although outcrops of the upper interval are more widely exposed.
An olive brown silty fine sandstone $(<30 \mathrm{~cm})$ forms the basal unit of section PNG-LY01 upon which the Moiti Tuff (15-30 cm; K93-6040) lies. The tuff is preserved well, has wave ripple-marks, and is coarse-grained. About $1.3 \mathrm{~km}$ west of section PNG-LY01, along the eastern bank of the Lenderit drainage, the Moiti Tuff preserves trace impressions of leaf blades and stems $1-2 \mathrm{~cm}$ wide that resemble swamp grass. It is overlain by a pale brown silty fine sandstone $(\sim 16 \mathrm{~m})$ that is thinly bedded and loosely cemented, and capped by an indurated calcite-cemented bed (10-15 $\mathrm{cm}$ ). The next bed is a pale brown, silty, massive claystone $4.6 \mathrm{~m}$ thick. Overlying the claystone is a gastropod-packed unit $(\sim 15 \mathrm{~cm})$, broken pieces of which locally fill vertical desiccation cracks $10-20 \mathrm{~cm}$ wide and at least $5 \mathrm{~m}$ deep in the underlying claystone. The gastropod-packed sandstone is succeeded by a medium brown sandy claystone $(8 \mathrm{~m})$, with lenses of gastropod-packed sandstone (10-15 cm) $1.7 \mathrm{~m}$ above its base. Laterally, carbonate concretions are present in place of the gastropods. At the top of the sandy claystone a calcite-cemented bed $(10 \mathrm{~cm})$ contains sparse ostracods. The last two units are olive and brown claystones, $5.4 \mathrm{~m}$ and $4.5 \mathrm{~m}$ thick respectively. Recent basaltic gravels cover the section.

The erosional surface between the lower and the upper intervals of the Moiti-Lokochot Member locally contains sparse basaltic pebbles coated with limonite. The pebbly horizon is exposed at many locations where strata of the two intervals of the Moiti-Lokochot Member are exposed together, and it lies at the base of the Moiti-Lokochot Member where the lower interval is absent. At one location $\left(2.9510^{\circ} \mathrm{N}, 36.6653^{\circ} \mathrm{E}\right)$ about $1.7 \mathrm{~km} \mathrm{SSE}$ of Lokoya water hole the erosional surface overlies an upward-fining sequence of brown mudstones and sandstones that are at least $10 \mathrm{~m}$ thick, but whose contacts with the Lonyumun Member or the Moiti Tuff are not exposed. Strata of the upper interval of the Moiti-Lokochot Member overlie

\section{Moiti-Lokochot Member}

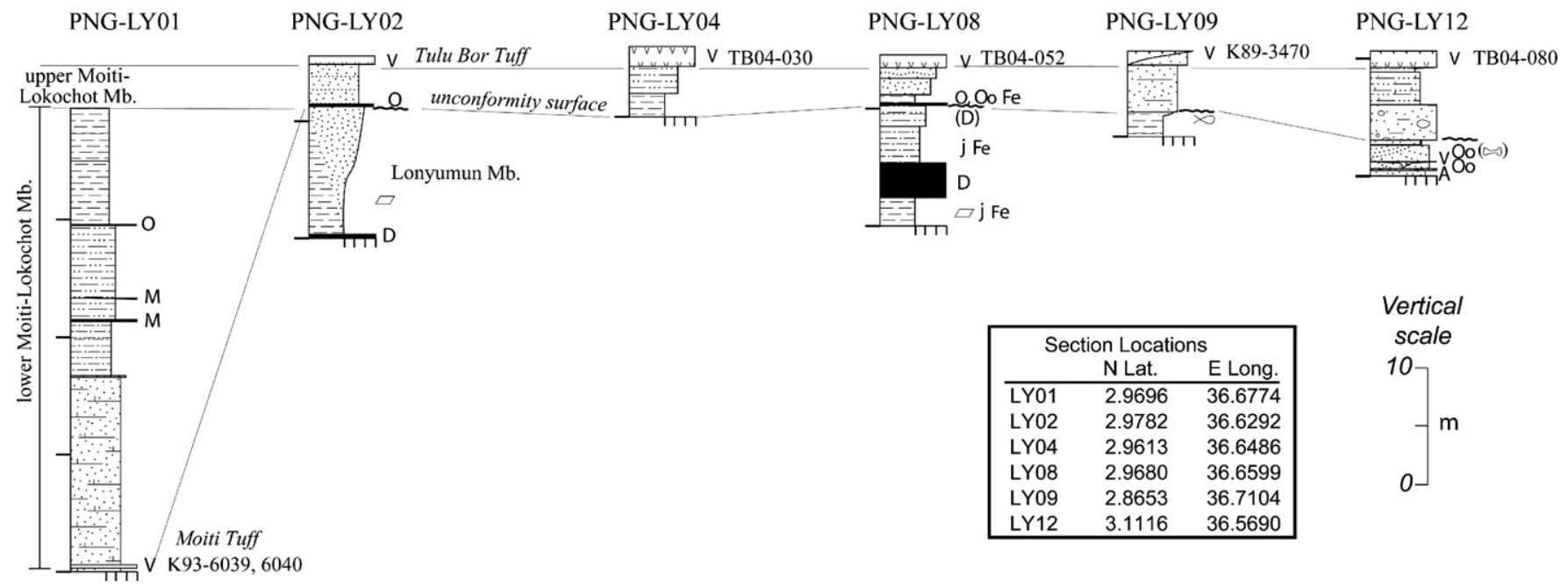

Fig. 6. Sections illustrating the stratigraphy of the Moiti-Lokochot Member of the Koobi Fora Formation in the Loiyangalani region. Section locations are shown in Fig. 1. See Fig. 5 for key to symbols used. 
the erosional surface west of this location. On the basis of this stratigraphic relationship, the bottom of the volcanic pebble conglomerate of section PNG-LY12 is locally adopted as the boundary between the Lonyumun and Moiti-Lokochot members.

Strata of the Moiti-Lokochot Member in section PNGLY12 represent the upper part of this member, although a thick conglomerate at the base makes the section thicker than typical $(3.6 \pm 0.8 \mathrm{~m})$ for the upper interval. Strata of the upper interval in the western Lenderit drainage also are generally thicker (at least $5 \mathrm{~m}$ ) and have basalt pebbles along the unconformity surface where strata of the lower interval are preserved. In section PNG-LY12 the conglomerate (granule to pebble, and $3 \mathrm{~m}$ thick) is overlain by reddish brown massive claystone and mudstone $(2.8 \mathrm{~m})$ with a prominent carbonate-cemented layer at the base. Next in the section is a laminated siltstone $(0.9 \mathrm{~m})$ capped by a calcite-cemented fine pebble conglomerate with a pyroxenerich sandy matrix and well rounded basaltic granules. In this section the member ends at the base of the $\beta$-Tulu Bor Tuff (TB04-080, Table 1).

Strata of the upper interval of the Moiti-Lokochot Member comprise the entire exposure of the member at many localities: directly south of Altuo water hole, along the eastern part of the Lenderit drainage, east and southwest of Lowasera, at isolated outcrops $8.5 \mathrm{~km}$ east of Lowasera (along SW-NE part of the road to Koobi Fora), and around Kankam. At all these localities the upper interval is underlain by the ostracod-packed sandstone whose base lies at the local top of the Lonyumun Member (see Figs. 5 and 6). The Tulu Bor Tuff overlies deposits of the upper interval in all locations.

In section PNG-LY05 the upper interval of the MoitiLokochot Member is $2.8 \mathrm{~m}$ thick (Fig. 5). It begins with an ostracod-packed sandstone $(10-20 \mathrm{~cm})$ followed by a silty, pale brown fine sandstone $(1.7 \mathrm{~m})$, and ends with a light brown, medium-grained, indurated sandstone $(0.9$ $\mathrm{m})$. The topmost sandstone has well-cemented elongate sand bodies (10-20 cm in diameter) with long axes oriented about $210^{\circ}$. In this section the interval is overlain by the Tulu Bor Tuff deposited in an ancient channel. Farther south (section PNG-LY02, Fig. 6) the upper interval is $3.4 \mathrm{~m}$ thick, and is composed of a pale yellow silty sandstone with laminated silt in the lower part, and with micro-tubules (probably grass rootlets) stained brown from iron oxide in the upper part. Still farther south (section PNG-LY04, Fig. 6) the upper interval is slightly thicker $(4.5 \mathrm{~m})$ and the ostracod-packed sandstone marker $(10$ $20 \mathrm{~cm}$ ) is overlain by a pale yellow bentonitic claystone $(2 \mathrm{~m})$, succeeded by a brown, massive, silty, fine sandstone $(2.3 \mathrm{~m})$ at the top.

The upper interval of the Moiti-Lokochot Member has many similarities in lithology and thickness northwest and north of Lokoya water hole as is shown in sections PNGLY04 and PNG-LY08 (Fig. 6), respectively. Strata of this interval in PNG-LY08 are $4.2 \mathrm{~m}$ thick, and begin with the ostracod-packed sandstone $(0.2 \mathrm{~m})$ followed by a pale brown claystone $(0.9 \mathrm{~m})$ that contains a pink bentonite layer. The last unit in this section is a sandstone $(2.3 \mathrm{~m})$ indurated in the lower $1.4 \mathrm{~m}$ and friable in the upper 0.9 $\mathrm{m}$. The top surface of this interval is truncated by a channel (oriented $185^{\circ}$ ) filled by deposits of the $\alpha$-Tulu Bor Tuff just as in the sections described above except for section PNGLY12. In section PNG-LY09 (Fig. 6), the upper interval is lithologically unique and composed entirely of a pale grayto-white sandstone $(4 \mathrm{~m})$ that is laminated and contains micro-tubules similar to grass rootlets.

\subsection{Tulu Bor Member}

In this region strata of the Tulu Bor Member have a composite thickness of $40 \mathrm{~m}$, and its deposits occur in two stratigraphic intervals separated by an angular unconformity and, locally, by basalt flows. The lower interval, here termed the lower Tulu Bor Member, is up to $32.7 \mathrm{~m}$ thick and includes a basalt flow $(6 \mathrm{~m}$, at the top of section PNG-LY09, Figs. 7 and 8). Strata of the upper interval (termed here the upper Tulu Bor Member), are identified with certainty only at one small outcrop between Lokoya water hole and section PNG-LY11 (Fig. 8) where the Lokalalei Tuff $(2.53 \pm 0.03 \mathrm{Ma}$, McDougall and Brown, 2008 ) is exposed. The upper Tulu Bor Member is $7.1 \mathrm{~m}$ thick in section PNG-LY11.

In section PNG-LY09 the lower Tulu Bor Member begins with the $\alpha$-Tulu Bor Tuff $(1.2 \mathrm{~m})$ which is cross-laminated, packed with silt, and locally contains fossil fish, chelonian, and sparse mammalian bones. At this location an intact chelonian carapace is preserved in situ within the tuff. The tuff is overlain by a sandstone $(1.6 \mathrm{~m})$ rich in olive clay, which is in turn overlain by a conglomeratic sandstone $(0.1$ $\mathrm{m})$. Well-rounded fine pebbles of quartz and ferruginous carbonate concretions make up the conglomeratic sandstone. Abundant fish teeth and scales, together with sparse, fragmentary chelonian and mammalian bones are cemented together with the detrital grains. Next in the section is a clayey sandstone $(0.4 \mathrm{~m})$ which is capped by an ostracod-packed sandstone $(0.1 \mathrm{~m})$, which is then overlain by a tuffaceous ( $\beta$-Tulu Bor Tuff) unit $2.1 \mathrm{~m}$ thick.

A basaltic tuff (K90-4612, Table 1), which we name the Lokoya Tuff after the nearby water hole, lies between the $\alpha$ - and $\beta$-Tulu Bor Tuffs in many sections in the area,. Its type locality is at $2.9543^{\circ} \mathrm{N} 36.6683^{\circ} \mathrm{E}$, where it is about $25 \mathrm{~cm}$ thick and very well exposed. It is also present, but thinner, in the Komote drainage, and between Lokoya and Balo.

The $\beta$-Tulu Bor Tuff in section PNG-LY09 is cross-laminated, rich in silt, and contains sparse fragmentary fish, chelonian, and mammalian fossils. Locally sandstones $(0.6$ $\mathrm{m})$ fill channel-form scours in the upper part of the unit. A clayey sandstone $(2.4 \mathrm{~m})$ capped with an ostracod-packed sandstone $(0.1 \mathrm{~m})$ overlies the tuff. Next is an upward-coarsening sequence $(6.5 \mathrm{~m})$ that begins as a clay-rich mudstone and grades vertically into coarse sandstone stained brown with iron oxide. This bed is followed by a second, thinner 


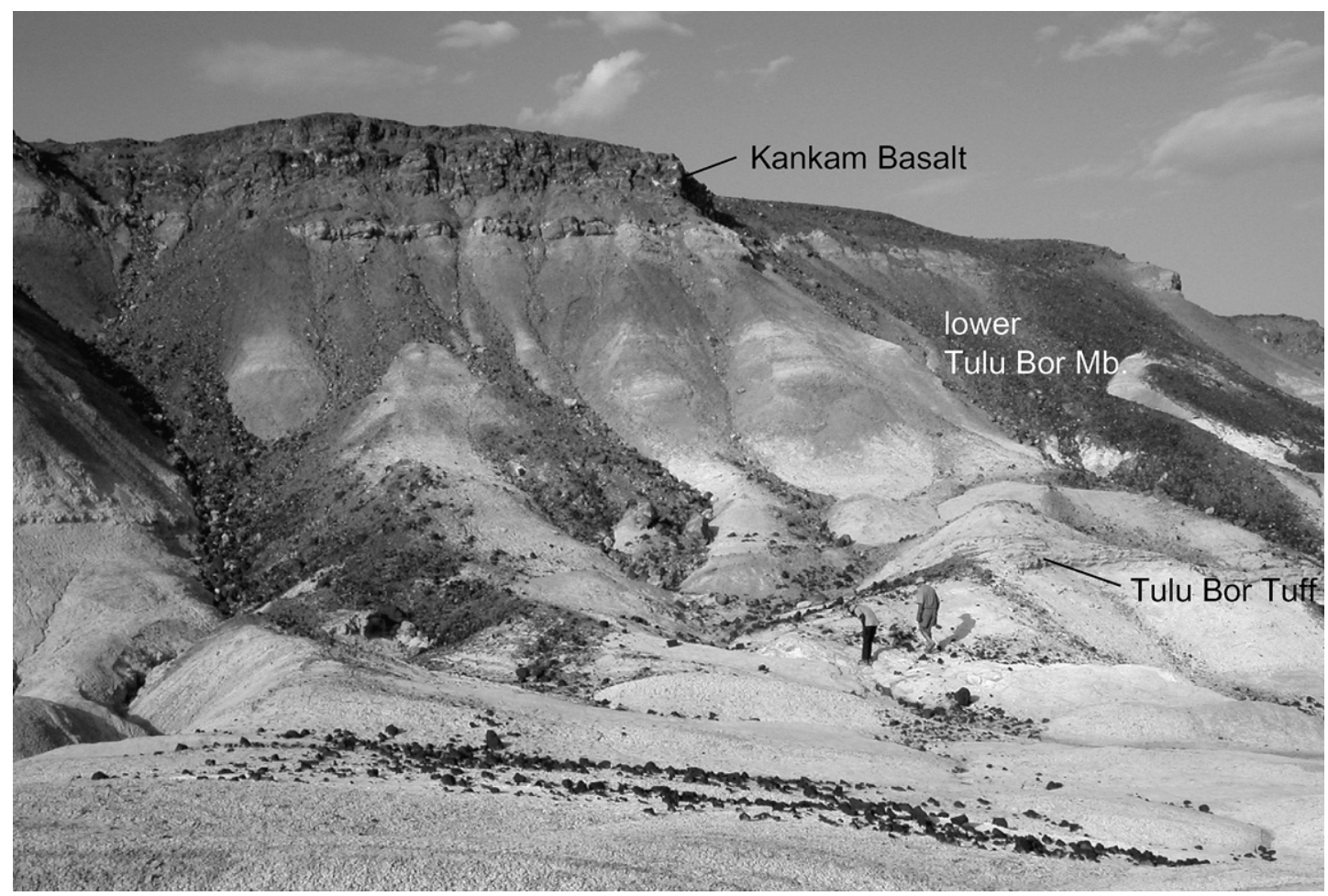

Fig. 7. Image of lower Tulu Bor Member overlain by the Kankam Basalt at Kankam, where section PNG-LY09 was measured; view to ENE. Light toned strata below the Kankam Basalt contain abundant sponge spicules (Potamophloios sp.).

\section{Tulu Bor and lower Burgi Members}

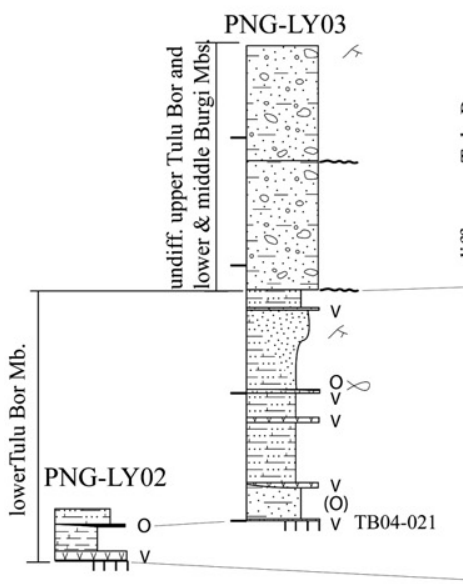

PNG-LY04

PNG-LY08

PNG-LY11

\begin{tabular}{|lcc|}
\hline \multicolumn{3}{|c|}{ Section Locations } \\
N Lat. & E Long. \\
\hline LY02 & 2.9782 & 36.6292 \\
LY03 & 2.9786 & 36.6272 \\
LY04 & 2.9613 & 36.6486 \\
LY08 & 2.9680 & 36.6599 \\
LY09 & 2.8653 & 36.7104 \\
LY10 & 2.8473 & 36.7099 \\
LY11 & 2.9396 & 36.6634 \\
LY12 & 3.1116 & 36.5690 \\
\hline
\end{tabular}
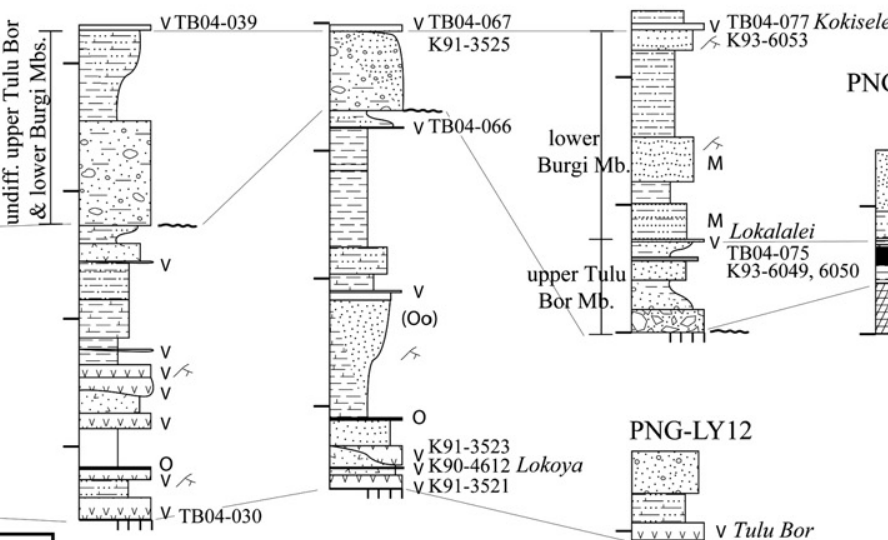

PNG-LY10
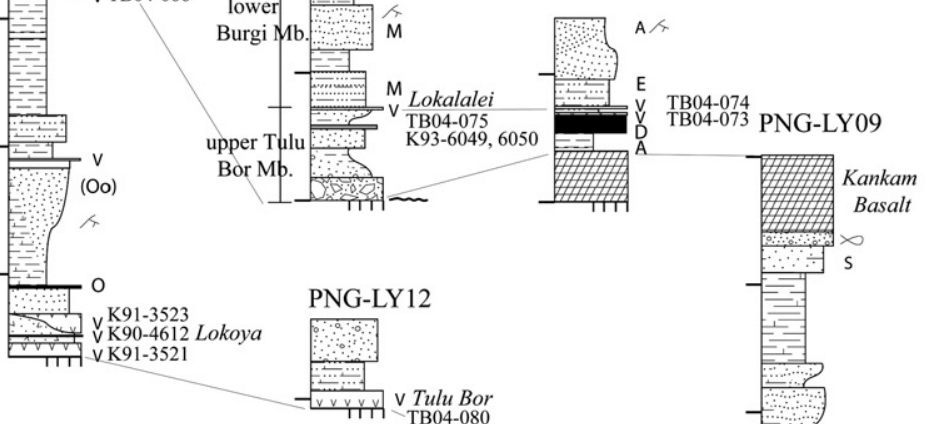

$\left.\begin{array}{c}\text { Vertical } \\ \text { scale } \\ 10 \\ { }^{10} \\ - \\ 0\end{array}\right] \mathrm{m}$

Fig. 8. Sections illustrating the stratigraphy of the Tulu Bor and Burgi Members of the Koobi Fora Formation in the Loiyangalani region. Section locations are shown in Fig. 1. See Fig. 5 for key to symbols used.

(1.9 $\mathrm{m}$ ) upward-fining sequence that begins as an olive clayrich mudstone and grades to a pale brown sandstone. This second upward-fining sequence is overlain by $7.1 \mathrm{~m}$ of inter- bedded siltstone and olive claystone followed by a second interbedded unit $(2.1 \mathrm{~m})$ that consists of siltstone and pale brown fine sandstone. Sponge spicules (amphistrongyla) 
are common in the upper sandy parts of this second interbedded unit. The last unit in this section is a conglomerate $(1.1 \mathrm{~m})$ that consists of oblate fine pebbles of calcite-cemented, ferruginous siltstone and coarse sandstone concretions. Fish bones and teeth are common in the conglomerate. Crocodile bones and fragments of very weathered mammalian bones also occur in the conglomerate elsewhere east of Kankam. The section is capped by a plateau basalt $(6 \mathrm{~m})$ locally with associated dikes.

The basalt that caps section PNG-LY09 is here formally named the Kankam Basalt, with its type locality defined at $2.8658^{\circ} \mathrm{N}, 36.7125^{\circ} \mathrm{E}$. It is a porphyritic rock with a groundmass of plagioclase feldspar, augite that is purplish (titaniferous) near the edges, and iron-titanium oxides. Phenocrysts are dominantly olivine, but plagioclase and augite also occur. In some samples, vugs are filled with calcite, and thin veins of chalcedony are present in others. Interstitial glass has been altered to clots of chlorite in most sections. In one thin section (K04-303), the olivine is altered to talc. A sample from this group of basalts near Gobele Spring contains a small amount of sodalite, and the olivine is altered to iddingsite.

At least two other basalts show an intrusive and possible temporal relationship with the Kankam Basalt in the Kankam area and elsewhere in the Loiyangalani region, so relations are similar to those in the Gombe Group basalts described above. Henceforth the term Kankam Basalt is used to refer to these related synchronogenic basalts. The lavas of the Kankam Basalt form the most extensive volcanic outcrop in the Loiyangalani region, and constitute the largest portion of Pliocene outcrops in the region extending east of the study area.

The base of the upper Tulu Bor Member is here informally defined at the top of the Kankam Basalt or correlative surfaces along the base of a conglomerate composed of basalt pebbles (presumably eroded from the Kankam Basalt). The conglomerate is common where the lava flows of the Kankam Basalt are absent, and it has an angular discordance of up to $4^{\circ}$ in relation to underlying strata. Stratigraphic relationships between the Kankam Basalt, the conglomerate, and the angular disconformity are perceptible on a south-north transect along Lenderit. Along this transect a Kankam Basalt overlies the lower Tulu Bor Member at a small hill in the middle of the southern part of the Lenderit drainage. There are no conglomeratic strata below the basalts on the hill, but a conglomerate rich in fine pebbles of basalt is common to the north (e.g., at base of section PNG-LY11) where the basalts are absent. This conglomerate correlates with another one exposed farther north (section PNG-LY08, Fig. 8) along the same transect, which directly overlies an angular disconformity that marks the top of the lower Tulu Bor Member. Strata of the upper Tulu Bor Member in section PNG-LY11 are described below.

Section PNG-LY11 (Fig. 8) begins with a matrix-supported conglomerate $(1 \mathrm{~m})$, but its base (the angular disconformity that marks the base of the upper Tulu Bor
Member) is not exposed. The dominant clasts are oblate $(\sim 0.5 \times 1 \times 2 \mathrm{~cm})$ basalt pebbles with pyroxene phenocrysts, but sparse quartz and feldspar are also present. Next in section is an upward-fining sequence $(2.1 \mathrm{~m})$ that begins as very fine sandstone and grades upward to a brown claystone. Basalt clasts are sparse in the lower part of this sequence, and instead quartz and pyroxene are common. The sequence is capped by a carbonate (?caliche) bed 10 $20 \mathrm{~cm}$ thick. Above this carbonate lies a calcite cemented, pale yellow, fine sandstone $(1.5 \mathrm{~m})$ with abundant carbonate concretions which is overlain by a sandy carbonate (?caliche) bed $(0.3 \mathrm{~m})$ along an irregular surface. The carbonate bed is overlain by an upward-coarsening sequence $(1.2 \mathrm{~m})$, which grades from olive brown claystone in the lower part to a pinkish red medium-grained sandstone at the top. The sequence is overlain by the Lokalalei Tuff $(2.53 \pm 0.03 \mathrm{Ma}$; McDougall and Brown, 2008). The Burgi Tuff whose base is defined as the formal top of the Tulu Bor Member by Brown and Feibel (1986) has not been identified in the study area, and therefore we employ the base of the Lokalalei Tuff, which lies not far above the Burgi Tuff in the Koobi Fora region, as the provisional top of the upper Tulu Bor Member. Where the Lokalalei Tuff is not present the angular disconformity described above is employed as the top of the member.

\subsection{Burgi Member}

In composite section, the Burgi Member is the thickest $(102 \mathrm{~m})$ of the five members of the Koobi Fora Formation in the region. The Burgi Member sequence is discussed below as three informal stratigraphic divisions: the lower $(16.6 \mathrm{~m})$, middle $(46.1 \mathrm{~m})$, and upper $(39.7 \mathrm{~m})$ Burgi Members. Synchronogenic basalts are locally intercalated with the sedimentary rocks within the middle Burgi Member.

The best exposures of the lower Burgi Member are at section PNG-LY11 where the Lokalalei Tuff lies at the base (Fig. 8). The tuff $(0.2 \mathrm{~m})$ lies on a sharp contact with a surface topography of about $15 \mathrm{~cm}$, and it contains sparse pumice clasts $5-15 \mathrm{~cm}$ across with anorthoclase phenocrysts. Glass of the pumices, like that of the tuff itself, is of two compositions, which match each other (see Table 1). Next is $2.8 \mathrm{~m}$ of interbedded siltstones and fine sandstones (pale brown). Bleached biotite and microtubules (or rootlet traces) are common in this interbedded unit, and the upper part has calcite-cemented slabs $5-10 \mathrm{~cm}$ thick that locally contain abundant Cleopatra. Above the interbedded unit is an olive sandy claystone $(1.7 \mathrm{~m})$ with slickensides, and also with lenses rich in carbonate concretions. The claystone is overlain by a brown fine sandstone $(3.5 \mathrm{~m})$ composed dominantly of quartz with sparse pyroxene and other heavy minerals. Cementing the sandstone is a locally ferruginous calcium carbonate. Endocasts of Cleopatra, Bellamya, and bivalves similar to but slightly larger than other specimens assigned to Corbicula are present in this sandstone. Sparse rhizoliths $(15 \mathrm{~cm}$ diameter, $45 \mathrm{~cm}$ long) occur in the upper part of the sandstone. The sand- 
stone is overlain by a unit $6.8 \mathrm{~m}$ thick comprised of massive brown sandy claystone. The highest unit in the lower Burgi Member in this section is a fine sandstone $(1.6 \mathrm{~m})$ pale brown in its lower part and pale yellow in its upper part with black blotches (up to $10 \mathrm{~cm}$ diameter), and rhizoliths up to $1 \mathrm{~cm}$ in diameter. Mineralogically the sandstone consists of quartz, pyroxene, bleached biotite, and other heavy minerals. The base of the Kokiselei Tuff $(\sim 2.43 \pm 0.05 \mathrm{Ma})$ is the top of the lower Burgi Member in the region.

Some Burgi Member strata that confine the Kokiselei Tuff in the region have correlative strata in the Nachukui and Shungura formations, but not in exposures of the Koobi Fora Formation in its type area. The term middle Burgi Member is particularly suitable as a name for strata between the Kokiselei Tuff and overlying Lenderit basalts (see below; Fig. 9) in this region since neither are recorded in the Burgi Member of Brown and Feibel (1986) in the northern East Turkana region. Thus the middle Burgi Member, which makes up $46.1 \mathrm{~m}$ in section PNG-LY08 (Fig. 10), is treated as separate from the lower and upper Burgi Members of Brown and Feibel (1986). We believe that strata of the lower and upper Burgi Members of the Loiyangalani region are essentially coeval with strata of the lower and upper Burgi Members in the Koobi Fora region defined by Brown and Feibel (1986).

The middle Burgi Member in section PNG-LY08 begins with the Kokiselei Tuff $(0.5 \mathrm{~m})$, which is pale blue, wave rippled, laminated, and well sorted, and composed of medium-grained glass shards. Stem and leaf impres- sions that resemble swamp grass are preserved within it. The tuff retains these features and its thickness wherever exposed in the region, and in these respects it physically resembles the Moiti Tuff exposed nearby. Next in section is a unit $(6.7 \mathrm{~m})$ that begins with a brown mudstone and grades upward to a white, silty, fine-grained sandstone. The next unit $(2.2 \mathrm{~m})$ reverses grading, starting with a fine grained sandstone and ending with a brown mudstone. These units are followed by a thin $(0.1 \mathrm{~m})$ pinkish brown sandstone composed almost entirely of quartz. The unit that follows is a massive brown mudstone rich in pedogenic carbonates, truncated $34 \mathrm{~m}$ above its base by a fault. Along the fault complex, stratigraphically above the mudstone is a basalt $(1.3 \mathrm{~m})$ that is intercalated with the sedimentary sequence of the middle Burgi Member in outcrops south and southeast of Lokoya water hole. This and related basalts are here named the Lenderit Basalt.

A tuff of very distinctive composition occurs just below the Lenderit Basalt in section PNG-LY16 (Fig. 10), which we name here the Egales Tuff. Its type location is at $2.9585^{\circ} \mathrm{N}, 36.6406^{\circ} \mathrm{E}$, in a saddle between two flat-topped hills along a major footpath called Arot Egales. It has the highest $\mathrm{Al}_{2} \mathrm{O}_{3}$ content of any tuff yet analyzed from the Omo Group (Table 1), and compositionally is a quartz trachyte, possibly derived from a volcano farther south in the rift valley of Kenya.

The Lenderit Basalt includes all basalt flows that are synchronogenic with rocks that compose the El Molo

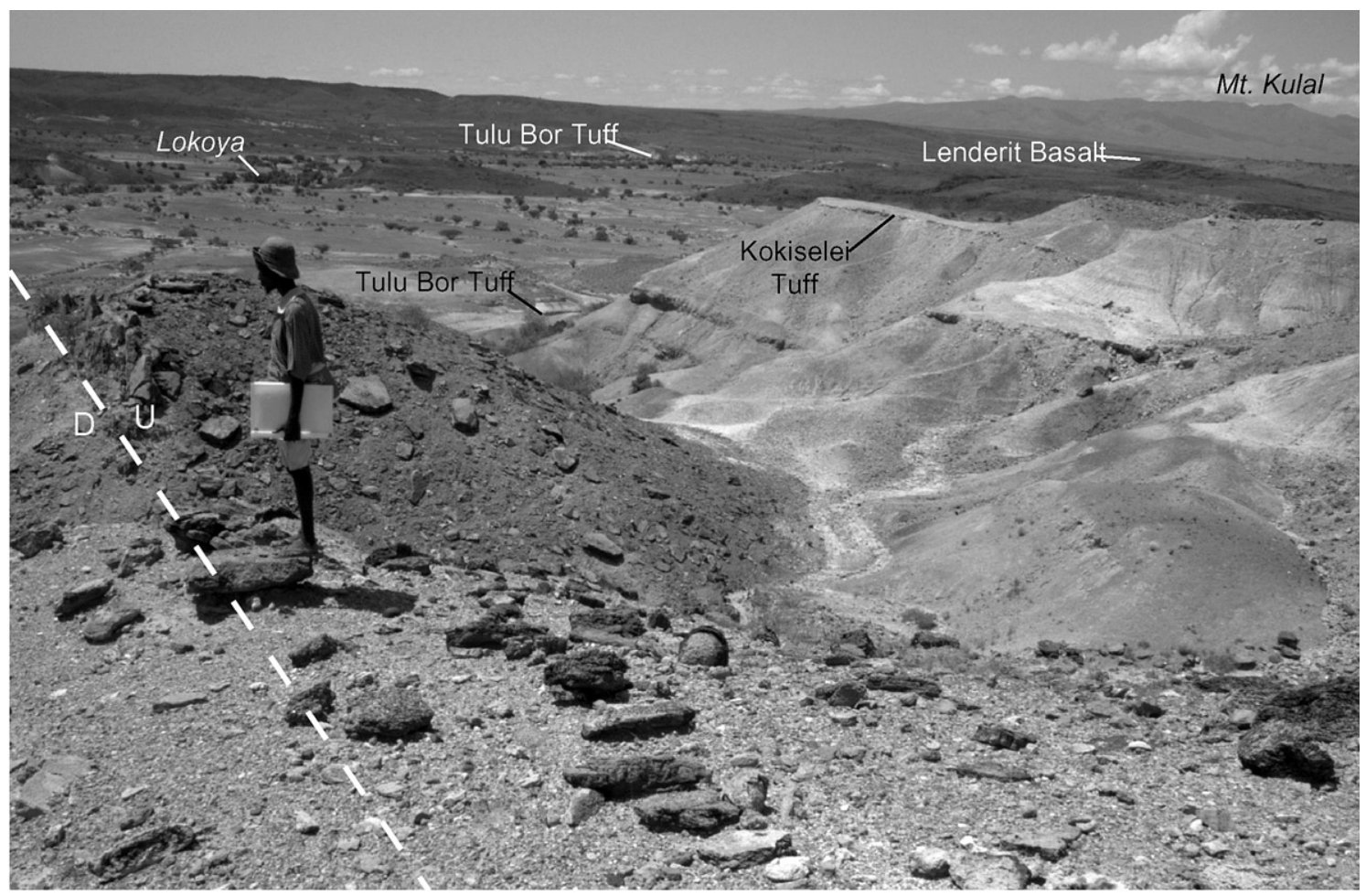

Fig. 9. Image showing the lower and middle Burgi Member, and the Lenderit Basalt where the top of section PNG-LY04 is located; view to southeast. Marko Barini is standing at the trace of a fault that cuts the section. 


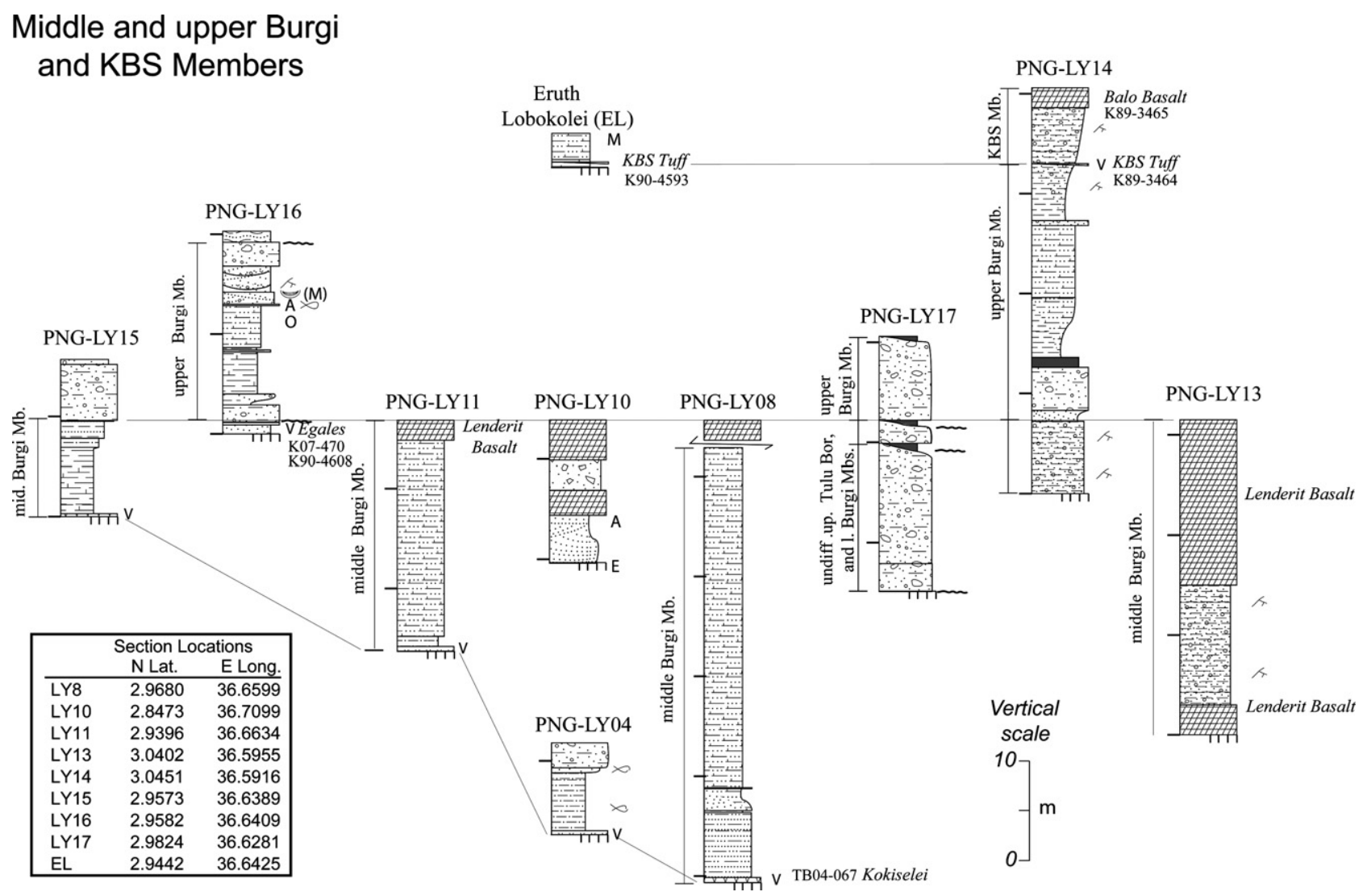

Fig. 10. Sections illustrating the stratigraphy of the middle and upper Burgi and KBS Members of the Koobi Fora Formation in the Loiyangalani region. Section locations are shown in Fig. 1. See Fig. 5 for key to symbols used.

Bay hills. Lavas of the Lenderit Basalt are also exposed at the top of the local section in the Kankam area where they overlie the Pliocene sedimentary section including the Kankam Basalt. A Lenderit Basalt (K04-375) from section PNG-LY09 is a sparsely porphyritic rock with small phenocrysts of augite and plagioclase (rarely also olivine) set in a groundmass of plagioclase, augite, olivine and $\mathrm{Fe}-\mathrm{Ti}$ oxides. Around edges and along cracks, olivine phenocrysts are altered to iddingsite, as are groundmass olivines.

Strata of the upper Burgi Member in the mapped area have only been identified southwest of Lokoya water hole, in the northwest part of the Balo drainage near section PNG-LY14 (Fig. 10), and north of Eruth Lobokolei. This sedimentary sequence lies on lavas of the Lenderit Basalt that locally confine a pebbly mudstone $(12 \mathrm{~m}$ thick in section PNG-LY13; Fig. 10), with locally abundant rhizoliths and carbonate concretions.

Section PNG-LY16 (Fig. 10) records $19.1 \mathrm{~m}$ of strata of the upper Burgi Member above the Lenderit Basalt. The Lenderit Basalt wedges out about $850 \mathrm{~m}$ southeast of this section, but the top of these basalts correlates with the base of a volcanic pebble conglomerate $1.2 \mathrm{~m}$ above the base of the section. This conglomerate $(1.7 \mathrm{~m})$ is dominated by pyroxene phyric basalt pebbles, and sparse metamorphic pebbles that are larger $(2-3 \mathrm{~cm}$ diameter) than the volcanic clasts. The conglomerate is overlain by a upward-coarsening sequence $(1.1 \mathrm{~m})$ that begins with dark brown claystone in the lower part and grades to a fine pebble (basalt, feldspar, and quartzite) conglomerate. Above this sequence is an interbedded unit $(4.2 \mathrm{~m})$ of pale gray and brown claystones and siltstones that are laminated and diatomaceous in the lower part.

The diatomaceous unit of section PNG-LY16 is overlain by a pale brown, laminated, fine-grained sandstone $(0.2 \mathrm{~m})$ immediately followed by a pale brown silty claystone $(0.25$ m) with preferentially-cemented regions that form prismatic vertical structures. Next in the section is a thinly bedded to laminated siltstone $(4.2 \mathrm{~m})$ that is pale brown (lower) to pale yellow (upper), and contains thin medium sandstone interbeds, and wave ripples. A thin $(0.05 \mathrm{~m})$ layer of volcanic pebbles occurs $0.4 \mathrm{~m}$ above the base of the unit. Ostracods are abundant in the upper quarter of the unit. The siltstone is overlain by a thin $(0.15 \mathrm{~m})$ basalt pebble conglomerate that contains flattened stromatolites (2.5 $\mathrm{cm}$ wide, $0.5 \mathrm{~cm}$ high), fish bones, and Piscichnus ( $\sim 1 \mathrm{~m}$ across). Next is a conglomeratic sandstone $(1.2 \mathrm{~m})$ that consists of basalt, quartz, and feldspar pebbles. Also in the sandstone are Piscichnus $(1 \times 0.15 \mathrm{~m}$; interlocking $)$, and endocasts of gastropods (Melanoides dominant), and bivalves (Pseudobovaria $<$ Mutela). The succeeding unit is a medium-grained sandstone $(2.6 \mathrm{~m})$ with foreset crossbedded conglomeratic lenses consisting dominantly of basalt pebbles $\sim 5 \mathrm{~cm}$ in diameter. A well-sorted, coarse sandstone $(0.6 \mathrm{~m})$ rich in rhizoliths occurs in the middle 
part of the unit. Next is a conglomerate $(2.4 \mathrm{~m})$ with wellsorted basalt pebbles. The last unit in this section is a pale to reddish brown siltstone $(1.1 \mathrm{~m})$, with a highly calcified, jagged, vesicular surface.

The upper Burgi Member in section PNG-LY14 (Fig. 10) lies on a pebbly mudstone $(7.2 \mathrm{~m})$ with abundant rhizoliths and carbonate concretions that correlates with the mudstone unit within the Lenderit Basalt in section PNG-LY13. Next is a sandy carbonate (?caliche) bed $(1.1 \mathrm{~m})$ with basalt pebbles on top. The top of this bed is considered contemporaneous with, or stratigraphically just overlying, the Lenderit Basalt that wedges out east and north of section PNG-LY13. The basalt pebbles at the top of the sandy carbonate may have been eroded from this basalt. The carbonate bed is overlain along a sharp contact by a upward-fining sequence $(4.3$ $\mathrm{m})$ that begins as basaltic pebble conglomerate and fines upward to pebbly mudstone. Overlying the upward-fining sequence is a white porcellaneous unit $(1 \mathrm{~m})$. This unit is contorted by soft sediment deformation, and has very pronounced slickenside surfaces. Next in section is a upward-coarsening sequence $(6 \mathrm{~m})$ with pinkish brown claystone in the lower part, a brown mudstone in the upper part, and a thin $(10-20 \mathrm{~cm})$ caliche horizon at the top. Above this is another pinkish brown claystone $(7.2 \mathrm{~m})$, capped by a thin $(0.5 \mathrm{~m})$ conglomerate composed of fine pebbles of basalt. The last unit of the upper Burgi Member in this section is an upward-coarsening sequence, in which the KBS Tuff $(1.869 \pm 0.021 \mathrm{Ma}$,
McDougall and Brown, 2006) lies $\sim 5.7 \mathrm{~m}$ above the base. This sequence consists of pebbly mudstone in the lower part, and the upper part is rich in sands, rhizoliths, and pedogenic carbonate concretions.

\subsection{KBS Member}

Locally strata of the KBS Member are at least $7.6 \mathrm{~m}$ thick, of which sedimentary strata compose about $5.5 \mathrm{~m}$ (section PNG-LY14, Fig. 10). Outcrops of this member have been identified only in the northwestern part of the region along the western margin of the Koobi Fora Formation outcrops, and in a small area north of Eruth Lobokolei. Local lenses of KBS Tuff at the base of the member are composed of pale gray and medium-grained shards. No pumice clasts were observed. The rest of the sequence is comprised of brown sandy-to-pebbly mudstone that fines upward, and is rich in rhizoliths and carbonate (pedogenic) concretions. Fine pebbles of basalt are present rarely in the sedimentary sequence, which is locally overlain by plateau basalts, here called the Balo Basalt that terminates against a fault on the west together with the KBS Member section.

The Balo Basalt at the top of section PNG-LY14 is vesicular, quite fresh, and composed principally of plagioclase, augite, olivine and $\mathrm{Fe}-\mathrm{Ti}$ oxides with microphenocrysts of the same phases. Alteration is restricted to rims of iddingsite on olivines microphenocrysts. The Balo Basalt is dated at $1.79 \pm 0.02 \mathrm{Ma}$ (Table 2).

Table 2

$\mathrm{K} / \mathrm{Ar}$ analytical data and ages of basalts from the Loiyangalani region and Mt. Kulal

\begin{tabular}{|c|c|c|c|c|c|c|}
\hline Sample & $\% \mathrm{~K}$ & ${ }^{40} \mathrm{Ar}^{*} \mathrm{~g}^{-1}\left(10^{-12} \mathrm{~mol}\right)$ & $\%{ }^{40} \mathrm{Ar}^{*}$ & Age $(\mathrm{Ma})$ & Error $(\mathrm{Ma})( \pm 1 \mathrm{SD})$ & Field number \\
\hline \multicolumn{7}{|c|}{ Longipi basalt, Serima Gorge $\left(2.521^{\circ} \mathrm{N}, 36.710^{\circ} \mathrm{E}\right)$} \\
\hline ANU92-438 & $0.984,0.983$ & 1.32 & 14.1 & 0.77 & 0.01 & K91-3540 \\
\hline \multicolumn{7}{|c|}{ Balo Basalt, Balo $\left(3.0431^{\circ} \mathrm{N}, 36.5780^{\circ} \mathrm{E}\right)$} \\
\hline ANU92-418 & $0.567,0.570$ & 1.77 & 21.5 & 1.79 & 0.02 & K89-3465 \\
\hline \multicolumn{7}{|c|}{ Gus basalt, west of Gus town $\left(3.0618^{\circ} \mathrm{N}, 36.8014^{\circ} \mathrm{E}\right)$} \\
\hline ANU92-425 & $0.807,0.802$ & 2.83 & 17.3 & 2.02 & 0.03 & K90-4581 \\
\hline \multicolumn{7}{|c|}{ Lenderit Basalt $\left(2.9547^{\circ} \mathrm{N}, 36.6577^{\circ} \mathrm{E}\right)$} \\
\hline ANU92-434 & $1.440,1.431$ & 5.03 & 23.2 & 2.02 & 0.02 & K91-3524 \\
\hline \multicolumn{7}{|c|}{ Lenderit Basalt $\left(2.9986^{\circ} \mathrm{N}, 36.6364^{\circ} \mathrm{E}\right)$} \\
\hline ANU92-436 & $1.174,1.167$ & 4.44 & 23.7 & 2.18 & 0.02 & K91-3534 \\
\hline \multicolumn{7}{|c|}{ Lenderit Basalt, Balo $\left(3.0325^{\circ} \mathrm{N}, 36.6015^{\circ} \mathrm{E}\right)$} \\
\hline ANU92-417 & $1.189,1.194$ & 5.19 & 54.6 & 2.51 & 0.03 & K89-3463 \\
\hline \multicolumn{7}{|c|}{ Kulal basalts $\left(\mathrm{K} 82-8032.522^{\circ} \mathrm{N}, 36.821^{\circ} \mathrm{E} ; \mathrm{K} 82-806,2.531^{\circ} \mathrm{N}, 36.918^{\circ} \mathrm{E} ; \mathrm{K} 82-805,2.962^{\circ} \mathrm{N}, 36.921^{\circ} \mathrm{E}\right)$} \\
\hline ANU83- 20 & $1.397,1.427$ & 5.01 & 65.5 & 2.04 & 0.02 & K82-803 \\
\hline ANU83- 22 & $1.357,1.357$ & 4.95 & 52.9 & 2.10 & 0.02 & K82-806 \\
\hline ANU83- 21 & $0.859,0.858$ & 3.57 & 34.0 & 2.40 & 0.03 & K82-805 \\
\hline \multicolumn{7}{|c|}{ Basalt on Gus-Lowasera road $\left(2.995^{\circ} \mathrm{N}, 36.771^{\circ} \mathrm{E}\right)$} \\
\hline ANU87- 35 & $0.656,0.654$ & 4.47 & 24.7 & 3.93 & 0.07 & K85-2731 \\
\hline \multicolumn{7}{|c|}{ Gombe Group basalts ( $\mathrm{K} 91-3538$, Lenderit, $2.982^{\circ} \mathrm{N}, 36.633^{\circ} \mathrm{E} ; \mathrm{K} 90-4580$, Furaful, $3.117^{\circ} \mathrm{N}, 36.735^{\circ} \mathrm{E}$ ) } \\
\hline ANU92-437 & $0.704,0.704$ & 5.16 & 18.4 & 4.22 & 0.06 & K91-3538 \\
\hline ANU92-424 & $0.816,0.816$ & 5.53 & 52.4 & 3.91 & 0.04 & K90-4580 \\
\hline
\end{tabular}




\section{Depositional environments}

The preceding description of Pliocene strata in the Loiyangalani region supplies considerable information for interpreting depositional environments. The terminology and criteria used below are based on Brown and Feibel (1986, 1991), Feibel (1988), Gathogo (2003), and Gathogo and Brown (2006).

\subsection{Lonyumun Member}

Deposition of this member in the region began a little over $4 \mathrm{Ma}$ ago in the early Pliocene on metamorphic basement rocks. The yellow, limonite-stained, sandstones underlying Gombe Group basalts in the region are consistent with deposits laid down by distributary channels in delta plain depositional environments or on broad playas. These sandstones are well-sorted, and have large scale foreset crossbeds at many locations including Lowasera. Transitional margins of the depocenter of the basin are evident at some locations near Lowasera, and are indicated by endocasts of Bellamya, a gastropod that is characteristic of shallow water along freshwater lakes and large rivers (Brown, 1994). Plaziat and Younis (2005) observe that Bellamya lives on the bottom muds of ponds, marshes and marsh channels, and that "during flood high waters, the empty shells float and are stranded up to the edge of peripheral emergent relief in marsh areas, thus delineating high water marks." The thickness and consistency in the sedimentary characteristics of these yellow sandstones implies that the basin was subsiding at a relatively fast rate, hence creating accommodation space to support and sustain deltaic and marginal lacustrine depositional environments before intrusion of the Gombe Group basalts began at $\sim 4.0 \mathrm{Ma}$ (Haileab et al., 2004).

Gombe Group basalts were locally intruded as sills into metamorphic rocks along the regional foliation (e.g., in the Lowasera area), as dikes into Lonyumun Member strata, and they were also erupted from small central vents (e.g., in the Altuo area, and at Nakilio hill). Some eruptions produced small volumes of basaltic tuff which were deposited very locally. Flows from the initial phase of eruption covered vast parts of deltaic and marginal lacustrine environments in the Loiyangalani region where they overlie well sorted sandstones, which are now yellow because of diagenetic staining with iron hydroxide. The eruptive interval was short (Haileab et al., 2004), but long enough for deposition of sedimentary strata between the flows.

An extensive pelagic lake, the Lonyumun Lake (Brown and Feibel, 1991; Haileab et al., 2004), covered most of the region just prior to the final eruptions of the Gombe Group basalts, and diatomaceous claystones were deposited in this lake. The transition from deltaic to pelagic lacustrine depositional environments is evident from sedimentary facies recognizable in strata that are confined between the basalts. Central volcanoes of Gombe Group basalts formed islands in the lake, and mollusc-rich sedi- ments formed locally in shallow waters around such centers (e.g., in Altuo, at section PNG-LY05, and PNG-LY06).

Stromatolites formed on the basalts in areas where volcanic bedrock was submerged at shallow depth under the lake (e.g., at section PNG-LY12, and near Altuo at $\left.2.9718^{\circ} \mathrm{N}, 36.6282^{\circ} \mathrm{E}\right)$. The flattened shape of the stromatolites in addition to the presence of oolites indicates locally shallow water (in an otherwise rather deep lake) above the basaltic bedrock, which was a likely source of abundant calcium. Cohen and Thouin (1987) describe a modern analogue of lacustrine oolites in Lake Tanganyika, where oolitic sand shoals $1-10 \mathrm{~km}$ long and $0.5-1 \mathrm{~km}$ wide accumulate parallel to the lake shore. Oolites in Lake Tanganyika are common on flat, shallow (0-4 m deep) platforms that "correspond closely to the zone of daily, non-storm, wave agitation" (Cohen and Thouin, 1987). Flattened (0.1-0.2 m high, 1-2 m wide) stromatolites occur below wave agitation depth (20-25 $\mathrm{m}$ deep), whereas taller $(0.2-0.5 \mathrm{~m}$ high $)$ stromatolites occur deeper $(25-30 \mathrm{~m}$; Cohen and Thouin, 1987). Davaud and Girardclos (2001) discuss environmental conditions under which oolites form along the margins of freshwater lakes, and show that in these settings the oolites and stromatolites are similar in internal structures thus indicating common formation processes. Diatomaceous claystones in other parts of the region indicate that the lake was pelagic until $\sim 3.95 \mathrm{Ma}$, when the Moiti Tuff was laid down, locally under deltaic conditions with extensive marshlands. Yuretich (1979) reports that at present diatomaceous clays and olive clays accumulate in the southern basin of modern Lake Turkana.

\subsection{Moiti-Lokochot Member}

The Moiti Tuff was locally deposited as an airfall ash in pelagic lacustrine environments of the Lonyumun Lake. Ripple-laminated exposures of the tuff at the base of section PNG-LY01 (Fig. 6) and isolated exposures with root casts preserved in the tuff indicate wetlands with shallow water, dominantly vegetated with swamp grass along the lake. Deposits composing this member in section PNGLY01 are consistent with low energy and repeatedly flooded lowlands where pedogenic carbonates are locally associated with thin mollusc-packed sandstones. Similar conditions are found on the modern delta plain of the Omo River.

Upward-fining mudstones of the lower Moiti-Lokochot Member at isolated outcrops southwest of Lokoya water hole show the earliest evidence for deposition of materials by a large river in the region. These strata (younger than those at section PNG-LY01) are consistent with floodplain deposits of the Omo River.

At most locations, sedimentation of the upper MoitiLokochot Member began on strata of the Lonyumun Member. These sediments were laid down in low energy depositional environments that possibly indicate flooded mudflats on a prograding delta plain or regressing lake, 
along the margin of which ostracod-packed sandstones were laid down. These shallow water marginal lacustrine deposits are followed by deltaic progradation by the Omo River which deposited the strata just underlying the Tulu Bor Tuff in the region.

\subsection{Tulu Bor Member}

The Tulu Bor Member was deposited in two time intervals divided here into the lower and the upper Tulu Bor Members. Deposition of the lower Tulu Bor Member began conformably on floodplains and in channels of the Omo River on top of the Moiti-Lokochot Member.

The general depositional slope at the beginning of the lower Tulu Bor Member was to the southeast, and both the $\alpha$-Tulu Bor and $\beta$-Tulu Bor Tuffs were deposited by a meandering river of a scale consistent with that of the modern Omo River in its lower reaches. The Tulu Bor Tuff fills a river valley of the meandering Omo River at several locations: (1) near section PNG-LY12, (2) in the Altuo area, (3) near Lokoya water hole, (4) in the Lowasera area, and (5) in isolated outcrops northeast of Lowasera along the road to Koobi Fora. Paleoflow directions and sedimentary features in a large channel filled with the tuff at the last location above imply that the Omo River exited the Loiyangalani region flowing generally toward the east.

The time interval between deposition of the $\alpha$-Tulu Bor and $\beta$-Tulu Bor Tuffs was sufficient to allow deposition of a minor basaltic tuff from a local eruption as an airfall ash (Table 1; K90-4612). The source of the basalt has not been identified, but it is likely to be near section PNG-LY17 since the tuff is thicker and composed of larger volcanic debris there than elsewhere in the region. Further, the Omo River floodplain in the region was concomitantly flooded at various locations during the time between deposition of the $\alpha$-Tulu Bor and $\beta$-Tulu Bor Tuffs. This is evident from oolites, ostracod-packed sandstones, gastropods, and chelonia in association with pedogenic carbonate, rhizoliths, and mammalian fossils at some locations. These environments persisted for most of the time during deposition of the lower Tulu Bor Member, especially near Kankam where olive claystones and ostracod-packed sandstones are common. Distal floodplain depositional environments were characteristic of the region for the remainder of the lower Tulu Bor Member. However, marginal lacustrine and alluvial fan deposits were laid down at some locations where the section was later covered by lavas of the Kankam Basalt (e.g., in the Kankam area). In the eastern part of the drainage at Lowasera the interval above these basalts is composed of yellow (limonite-stained) well sorted deltaic sandstones ( $>10 \mathrm{~m}$ thick) similar to those below the Gombe Group basalts. These we interpret as deltaic and marginal lacustrine deposits.

Kankam Basalt lavas that form the top of the Pliocene section at many places in the region are thick and extensive in the eastern part of the region. In a few locations where a sedimentary sequence overlies the basalts, diatomaceous olive claystones overlie and are intruded by the basalts in the same way as Gombe Group basalts intrude strata deposited in the Lonyumun Lake. This association between the Kankam Basalt lavas and the diatomaceous olive claystones indicates that the relationship is syntopogenic with that of the Gombe Group basalts and their diatomaceous olive claystones deposited in pelagic lacustrine settings.

The upper Tulu Bor Member began with deposition of olive claystones in an extensive lake, similar to the Lonyumun Lake, covering the Kankam Basalt in the eastern parts of the Loiyangalani region including the Kankam area and extending at least $4 \mathrm{~km}$ south of Loiyangalani town. As the lake began to form, stromatolites were common in relatively shallow areas, where the basalts provided a rich source of calcium. The dependency of these stromatolites on the basalts is apparent east of Loiyangalani town where a narrow pavement of interlocked stromatolites lies on olive claystone superjacent fissure filled with calcite that extends down to the underlying Kankam Basalt. Further, the stromatolites are common only next to basalt or where the basalts are thinly $(<0.5 \mathrm{~m})$ covered by the olive claystone. Abundant ostracods lived near the edges of this lake, as did burrowing invertebrates that formed an ostracodrich burrowed bed. This burrowed bed is one of the units commonly known as "Loiyangalani stone" that is mined locally for house construction because of its elaborate and aesthetic ornamentation with ostracods and trace fossils.

There is no geologic record to show how far the large lake at Kankam and areas to the south extended westward beyond the Lenderit drainage. The record instead indicates the presence of an undulating terrain, adjacent to the Kankam Basalt, with small streams that eroded higher areas and locally deposited small alluvial fans. Depositional rates were higher in the western parts of the region than in the east. This can be explained by considering tectonic and volcanic activities that occurred in the region at the time. In the Kankam area the lake sediments were intruded and overlain by basalt as part of the final stage of the Kankam Basalt eruptions. This was followed by major faulting and tilting events evident in the Lenderit area. A combination of these activities must have resulted in significant topographic changes that could have led to development of high energy deposition in alluvial fans in the western parts of the region and adjacent lacustrine facies in the eastern and southern parts of the region. Accordingly, low areas in the undulating landscape in the west were filled by deposits from local ephemeral streams before deposition by the Omo River resumed in most parts of the region.

Section PNG04-LY11 records deposits of the Omo system in the upper Tulu Bor Member (Fig. 8). These strata are confined between conglomerates at the base of the unit and the Lokalalei Tuff where clay-rich sediments were laid down on an intermittently inundated floodplain of the Omo River. Soil carbonates on the floodplain developed during emergent periods but with the water table elevated locally proximal to the river. Evidence for the presence of 
the Omo River in the region during deposition of the upper Tulu Bor Member is the association of channel-form sandstones at the top of this member with the Lokalalei Tuff, which contains rounded pumice clasts and is thus fluvial. The association of the tuff with Etheria elliptica south of Lokoya water hole affirms the perennial nature of the fluvial system. These E. elliptica are rugose and elongate, indicating a perennial river assemblage like those found along the modern Omo River, in contrast rounded, smoother forms that live in shallow littoral environments of large freshwater lakes such as Lake Victoria and the Holocene Galana Boi lake (see Gathogo, 2003).

\subsection{Burgi Member}

Deposition of the Burgi Member in the Loiyangalani region continued locally on floodplains of the Omo River but was interrupted by local volcanism during deposition of the middle Burgi Member. Sedimentation east of the Lenderit drainage became greatly reduced during Burgi Member times, and it is probable that the lower Burgi Member marks the last time that deposits were laid down by the Omo River in this part of the region.

Strata in section PNG04-LY11 (Fig. 8) indicate that local deposition of the lower Burgi Member continued concordantly with deposits of the Tulu Bor Member on floodplains of the Omo River. As noted above, the Lokalalei Tuff was deposited by a perennial fluvial system interpreted as the Omo River. Other evidence of the perennial nature of the fluvial system associated with floodplain deposits of the lower Burgi Member is adduced from abundant $E$. elliptica in the southern part of the Kankam area (section PNG04-LY10). Gastropods (section PNG04-LY11) in association with abundant rhizoliths indicate that floodplains of the Omo River were expansive and intermittently inundated. These environments persisted locally for much of the time recorded by the lower Burgi Member, and supported palustrine vegetation preserved in the Kokiselei Tuff. In these depositional settings sedimentation in the lower Burgi Member appears to have been minimally affected by local processes such as ephemeral streams.

Deposition of the middle Burgi Member began with the airfall Kokiselei Tuff on an expansive inundated floodplain of the Omo River. Wave ripples preserved in the tuff indicate gentle wind-induced wave action in shallow water. Olive claystones and upward-coarsening sequences of sandstones and siltstones below the Lenderit Basalt initially record distal deltaic depositional environments. Later these environments become fully fluvial, as evidenced by upward-fining sequences with channel sandstones associated with brown mudstones and claystones. The fluvial mudstones and claystones have abundant pedogenic carbonates and rhizoliths, and thus indicate deposition on floodplains.

Major changes in depositional environments in the middle Burgi Member began just before eruption of the Lenderit Basalt. These involved replacement of floodplains and channels of a meandering fluvial system by marginal lacustrine conditions and local alluvial streams. For example, in the Kankam area (section PNG05-LY10) the basalts overlie sandstones that are rich in rhizoliths, and locally contain stromatolites. Gastropod-packed sandstones deposited in lake margin settings are directly overlain, and intercalated with the Lenderit basalts south of Lokoya water hole.

Vesicle cylinders in the lower part of the Lenderit Basalt near Kankam are believed to result from injection of volatiles formed by air trapped beneath the advancing basalt flow together with absorption of gases and water vapor from the damp ground of the delta and lake margins. The base of the flow cooled first and became relatively static as is indicated by the vertical orientation of the vesicle cylinders, but still molten parts of the lava continued to flow and resulted in development of sub-horizontal pipe vesicles oriented in the direction of flow. These volatiles also interacted with the underlying sediments staining them to crimson red and maroon. Volcanic debris and agglomerates from active eruptive centers are preserved in sediments confined between different flows of the basalts at Kankam.

Lagasan and Lorian Gayo hills were volcanic centers for the Lenderit Basalt. Lagasan is composed of pyroclastic debris with interbedded basalts, and concentric features produced by the then active volcanic vents are apparent from the top of the hill. Lorian Gayo was an active volcanic fissure of these basalts oriented NNW. Vertical joints at least $5 \mathrm{~m}$ deep and at least $20 \mathrm{~m}$ long are oriented parallel to the direction of the main fissures, as are fissure fills. The general orientation of these features is consistent with the shape of this southern hill, and is either parallel or perpendicular to the strike direction of dikes of these basalts in the surrounding area. Similarly oriented features associated with the basalts include pipe vesicles, basalt flow wrinkles on top of the northern hill, and slickensides on the surfaces of the dikes.

Flows of the Lenderit Basalt fill channels cut into underlying sediments. At one location along the western bank of the Lenderit drainage these basalts are exposed in a narrow gully $<2 \mathrm{~m}$ above the Kokiselei Tuff. This gully is asymmetrical with the gently sloping side filled by the basalt flow that dips towards its center; the opposite, gently sloping side, is filled with pebble conglomerate that overlies the basalt. Strata beneath the basalts at this location were deformed after depositional deformation by the basalt intrusion and flow. Olive claystones, ostracod- and mollusc-rich sandstones, stromatolites, and Piscichnus in overlying strata indicate that lacustrine environments pertained through the remainder of the middle Burgi Member.

Sedimentation of the upper Burgi Member in the northwestern part of the region began just after eruption of the Lenderit Basalt and was initially dominated by local depositional environments with alluvial fans. The youngest units of this member records a complex interaction between two drainage systems: (i) floodplains of a major fluvial system, probably the Omo River, where thick claystones were deposited; and (ii) local alluvial fans and streams which 
deposited gravelly mudstones and sandstones with pebbles eroded from local Pliocene basalts. In southern exposures (PNG-LY16; Eruth Lobokolei) these conditions are replaced by lacustrine conditions during deposition of the youngest units of this member.

\subsection{KBS Member}

The KBS Member was laid down on alluvial plains. Abundant rhizoliths and pedogenic carbonates in the lower parts of this member show that environments were relatively arid but also that streams supplied water to support some vegetation. There is no evidence for a perennial drainage system in the region, and it is probable that the KBS Tuff was locally reworked from an airfall ash deposit. Deposits of this tuff are very localized, lenticular, and lack pumice clasts - all factors which are inconsistent with deposition by the Omo River. North of Eruth Lobokolei, a spring and mud volcano complex, the KBS Tuff appears to be an airfall tuff into a lake, because it is overlain by silty sandstones that contain abundant molluses.

Local depositional environments involving alluvial fans and streams became increasingly dominant in the upper part of the KBS Member, and sedimentation terminated following eruption of the Balo Basalt.

\section{Age estimates of the basalts}

For some basalts we measured $\mathrm{K} / \mathrm{Ar}$ ages on whole rock samples, selecting the least altered samples for dating. $\mathrm{K}-$ Ar measurements were made by methods similar to those described by McDougall and Feibel (1999). Potassium was determined by flame photometry and argon by isotope dilution using an ${ }^{38} \mathrm{Ar}$ tracer. Decay constants used were those recommended by Steiger and Jäger (1977). K-Ar data are listed in Table 2, where uncertainties in the ages are seen to average $1-2 \%$ standard deviation.

All basalts in the Loiyangalani region east of the Balo Fault are of Pliocene or lowest Pleistocene age because they are intercalated with securely dated strata of the Omo Group, and are contemporaneous with deposition of the Koobi Fora Formation in the region. These basalts are assigned to four synchronogenic groupings, namely the Gombe Group, Kankam, Lenderit, and Balo - from old to young. Each of the four units shows that some time lapsed between intra-group successive flows, but that time lapse is considered to be geologically brief except for the Lenderit basalts where direct age determinations show that it is at least $160 \mathrm{ka}$. These time lapses are believed to be of the same order of magnitude as those observed between the $\alpha$-Tulu Bor and $\beta$-Tulu Bor Tuffs, for example, which are locally separated by ostracod-rich sandstones and an airfall basaltic tuff, and in the Lomekwi area (West Turkana) by a paleosol that is rich in mammalian fossils and rhizoliths. The two layers of the Tulu Bor Tuff are believed to represent successive eruptions from the same source, but of approximately the same age.
The oldest basalts in the Loiyangalani region occur in stratigraphically identical context within the Lonyumun Member as Gombe Group basalts described from other parts of the Omo-Turkana Basin by Haileab et al. (2004). Two K-Ar ages on basalts assigned to the Gombe Group are close to $4 \mathrm{Ma}$, broadly consistent with the age of the Lonyumun Member.

Sample K85-2731 (ANU87-35; Table 2) lies above the Tulu Bor Tuff ( $3.44 \pm 0.02 \mathrm{Ma})$, yet it yielded an age of $3.93 \pm 0.07 \mathrm{Ma}$. Although the age is within the range encountered for many other Gombe Group basalts, its composition differs from basalts of that group, most notably in having a much lower $\mathrm{TiO}_{2}$ content $(1.67 \%$ vs. $3.5 \%$ for the Gombe Group). Thus the measured age, which is older than that of the underlying Tulu Bor Tuff, must result from a violation of the assumptions inherent in K/Ar dating - probably because of the presence of excess argon.

The Kankam Basalt lavas are confined between two dated units, the Tulu Bor Tuff and the Lokalalei Tuff, and are thus between 2.52 and $3.43 \mathrm{Ma}$ in age. They are associated with a short lacustrine sequence that lies below the Lokalalei Tuff which may correlate with a lacustrine sequence that contains the Waru Tuff. At Koobi Fora the Waru Tuff lies between the Allia Tuff and the Toroto Tuff in Areas 207 and 204, and it is also present (again with lacustrine sediments) at Topernawi west of Lake Turkana. Hillhouse et al. (1986) place this latter sequence within the Mammoth Event (3.21-3.33 Ma). On this basis, we tentatively suggest that the Kankam Basalt is 3.2-3.3 Ma old.

Lenderit Basalt lavas are confined between the Kokiselei Tuff and the angular disconformity that separates the upper and lower Burgi Members at most localities in the Koobi Fora (Brown and Feibel, 1986) and Ileret (Gathogo and Brown, 2006) regions. Various workers (e.g., Brown and Feibel, 1986, 1991; Gathogo and Brown, 2006) have shown that deposition of the upper Burgi Member was preceded by a major tectonic event that resulted in an angular disconformity over most regions in East Turkana. We believe that the same event led to development of a tectonic lake in the Loiyangalani region, and that the lake formed penecontemporaneously with lakes recorded in the Kalochoro Member of the Nachukui Formation (West Turkana) and upper Member G of the Shungura Formation. Two direct ages have been measured on samples of Lenderit basalts, one $2.18 \pm 0.02 \mathrm{Ma}$ (Table 2), and another of $2.02 \pm 0.02 \mathrm{Ma}$ (Table 2) on the basalt that caps the sedimentary sequence at Lenderit. This latter date is indistinguishable from the date $(2.02 \pm 0.03 \mathrm{Ma}$; Table 2$)$ on a basalt sample at the road junction $\left(3.0611^{\circ} \mathrm{N}\right.$, $36.8028^{\circ} \mathrm{E}$ ) to Gus along the road from Loiyangalani to Koobi Fora. One age determination on a Lenderit Basalt lava (ANU92-417; $2.51 \pm 0.03 \mathrm{Ma}$ ) appears to be older than allowed by stratigraphic constraints because it is believed to lie above the Kokiselei Tuff. Compositionally this basalt is indistinguishable from the basalt dated at $2.18 \pm 0.02 \mathrm{Ma}$ (ANU92-436), an age which agrees with the stratigraphic position of the Lenderit Basalt. Other 
basalts in the region (e.g., that at Lothagam; McDougall and Feibel, 1999) have yielded technically sound K/Ar ages that are inconsistent with their stratigraphic position, a reminder that individual ages should not be accepted uncritically.

Stratigraphically, the Balo Basalt is only constrained to be younger than the KBS Tuff $(1.87 \pm 0.02 \mathrm{Ma})$. Although no younger age limit can be set, a direct date on the Balo Basalt of $1.79 \pm 0.02 \mathrm{Ma}$ (Table 2) is consistent with its stratigraphic position.

\section{Discussion}

The geologic sequence in the Loiyangalani region is readily attributable to the Omo Group deposits, and we interpret it as part of the Koobi Fora Formation.

Previously used terms, 'Loiyangalani formation' (Ochieng' et al., 1988) and 'Loiyangalani Formation' (Rop, 1990), contravene provisions of the International Stratigraphic Code (Hedberg, 1976; Salvador, 1994; Murphy and Salvador, 1999) concerning formal names of geologic units. The code specifies that the formality of a unit is conveyed by capitalization of the initial letter of the term that depicts the unit's rank (e.g., Loiyangalani Formation, as opposed to Loiyangalani formation). Rop's (1990, Fig. 15) 'Loiyangalani Formation' is geographically, lithologically, and stratigraphically different from the proposed 'Loiyangalani formation' of Ochieng' et al. (1988). The former unit is exposed west of the Balo Fault, and is thus outside the part of the Loiyangalani region where the latter unit is described. No correlation of the two units is presented by Rop (1990) or in subsequent studies - indeed, they do not correlate. Further, according to Rop (1990), the former unit is composed of "over $200 \mathrm{~m}$ of fine-grained olivine basalts and subordinate, interbedded pyroclastics", as opposed to the latter which is described as a sedimentary rock unit (Ochieng' et al., 1988).

Geographic extension of the Koobi Fora Formation to include the Pliocene sedimentary sequence in the Loiyangalani region, and formal definition and naming of the intercalated Pliocene basalts (in addition to the Gombe Group basalts) follow from the International Stratigraphic Code (Hedberg, 1976; Salvador, 1994; Murphy and Salvador, 1999). This code provides priority to publication of a properly proposed, named, and described unit. Further, concerning usage of the informal name "Loiyangalani formation" by Ochieng' et al. (1988) to include Pliocene strata in the Loiyangalani region described by the current study, the code states that; "[l]ithostratigraphic units recognized in preliminary studies and not fully described and characterized are sometimes given names", and that "[s]uch names should be considered informal and should not be included in published documents" (Salvador, 1994). The code encourages reduction in number of names if the identity of two differently named stratigraphic units has been established through correlation, in which case the later name should be replaced by the earlier.

\section{Summary and conclusions}

Strata of the Pliocene members of the Koobi Fora Formation (Brown and Feibel, 1986) in the Loiyangalani region extend the known geographic area of the formation $100 \mathrm{~km}$ southward from the Koobi Fora region. These strata, amongst others, were previously termed 'Loiyangalani formation (or Formation).' Most importantly, this study demonstrates that deposition in the Loiyangalani region began at about the same time as in most regions in the Omo-Turkana Basin where the Koobi Fora and Nachukui formations occur.

Further we identify, describe, define, and name Pliocene basalts exposed in the region except for those of the Gombe Group. These newly named basalts are Kankam (3.2$3.3 \mathrm{Ma}$ ), Lenderit $(2.02$ to $2.18 \pm 0.02 \mathrm{Ma})$, and Balo $(1.79 \pm 0.02 \mathrm{Ma})$. We also report $\mathrm{K} / \mathrm{Ar}$ ages on three basalts from Mt. Kulal and one from Serima Gorge (Table 2), the former were erupted during the time that the Tulu Bor and Burgi Members were deposited, whereas the latter is considerably younger.

\section{Acknowledgements}

Financial support for field and laboratory work was provided by the L.S.B. Leakey Foundation, the College of Mines and Earth Sciences, University of Utah, the Research School of Earth Sciences, the Australian National University, and the National Science Foundation (BCS-0621542/001). To all of these entities, we are grateful, as we are to the people of the Loiyangalani region whose cooperation made the work feasible. Special thanks go to Justus Edung, Simon Ilar and Marko Barini, who increased our productivity immensely. The work was done under the auspices of the National Museums of Kenya.

\section{References}

Bowen, B.E., Vondra, C.F., 1973. Stratigraphical relationships of the Plio-Pleistocene deposits, East Rudolf, Kenya. Nature 242, 391-393.

Brown, D.S., 1994. Freshwater Snails of Africa and their Medical Importance, second revised ed. Taylor and Francis, London.

Brown, F.H., Feibel, C.S., 1986. Revision of lithostratigraphic nomenclature in the Koobi Fora region, Kenya. Quarterly Journal of Geological Society 143, 297-310.

Brown, F.H., Feibel, C.S., 1991. Stratigraphy, depositional environments and paleogeography of the Koobi Fora Formation. In: Harris, J.M. (Ed.), Koobi Fora Research Project, Stratigraphy, Artiodactyls and Paleoenvironments, vol. 3. Clarendon Press, Oxford, pp. 1-30.

Brown, F.H., Haileab, B., McDougall, I., 2006. Sequence of tuffs between the KBS Tuff and the Chari Tuff in the Turkana Basin, Kenya and Ethiopia. Journal of the Geological Society, London 163, 185-204.

Cerling, T.E., 1977. Paleochemistry of Plio-Pleistocene Lake Turkana and diagenesis of its sediments. Ph.D. Dissertation, University of California, Berkeley, pp. 185.

Cerling, T.E., Brown, F.H., 1982. Tuffaceous marker horizons in the Koobi Fora region and the lower Omo valley. Nature 299, 216-221.

Cohen, A.S., Thouin, C., 1987. Nearshore carbonate deposits in Lake Tanganyika. Geology 15, 414-418. 
Davaud, E., Girardclos, S., 2001. Recent freshwater ooids and oncoids from western Lake Geneva (Switzerland): indications of a common organically mediated origin. Journal of Sedimentary Research 71, 423429.

de Heinzelin, J. (Ed.), 1983. The Omo Group: Tervuren, Belgique, Musée Royal de l'Afrique Centrale, Annales, Série in 8o, Sciences Géologiques 85,365 .

deMenocal, P.B., Brown, F.H., 1999. Pliocene tephra correlations between East African hominid localities, the Gulf of Aden, and the Arabian Sea. In: Agusti, J., Rook, L., Andrews, P. (Eds.), Hominid Evolution and Climatic Change in Europe: The Evolution of Neogene Terrestrial Ecosystems in Europe. Cambridge University Press, Cambridge, pp. 23-54

Feibel, C.S., 1988. Paleoenvironments from the Koobi Fora Formation, Turkana Basin, northern Kenya. Unpublished Ph.D. Dissertation. University of Utah, Salt Lake City, pp. 330.

Gathogo, P.N., 2003. Stratigraphy and paleoenvironments of the Koobi Fora Formation of the Ileret Area, northern Kenya. M.S. Thesis, University of Utah, pp. 160.

Gathogo, P.N., Brown, F.H., 2006. Stratigraphy of the Koobi Fora Formation (Pliocene and Pleistocene) in the Ileret region of northern Kenya. Journal of African Earth Sciences 45, 369-390.

Gradstein, F., Ogg, J., Smith, A. (Eds.), 2004. A Geologic Time Scale 2004. Cambridge University Press, Cambridge, UK, p. 610.

Haileab, B., Brown, F.H., McDougall, I., Gathogo, P.N., 2004. Gombe Group basalts and initiation of Pliocene deposition in the Turkana depression, northern Kenya and southern Ethiopia. Geological Magazine $141,41-53$.

Harris, J.M., Brown, F.H., Leakey, M.G., 1988. Stratigraphy and paleontology of Pliocene and Pleistocene localities west of Lake Turkana, Kenya. Los Angeles Museum of Natural History. Contributions in Science 399, 1-128.

Harris, J.M. (Ed.), 1983. Koobi Fora Research Project. The Fossil Ungulates: Proboscidea, Perissodactyla and Suidae, vol. 2. Clarendon Press, Oxford, p. 321.

Harris, J.M. (Ed.), 1991. Koobi Fora Research Project. Stratigraphy, Artiodactyls and Paleoenvironments, vol. 3. Clarendon Press, Oxford, p. 384.

Hedberg, H.D. (Ed.), 1976. International Stratigraphic Guide - A Guide to Stratigraphic Classification, Terminology, and Procedure. John Wiley and Sons, New York, p. 220.

Hillhouse, J.W., Cerling, T.E., Brown, F.H., 1986. Magnetostratigraphy of the Koobi Fora Formation, Lake Turkana, Kenya. Journal of Geophysical Research 91 (B11), 11581-11595.

Isaac, G.L., Isaac, B. (Eds.), 1997. Koobi Fora Research Project. Archeology, vol. 5. Clarendon Press, Oxford, p. 596.

Key, R.M., Watkins, R.T., 1988. Geology of the Sabarei area. Report of the Mines and Geology Department, Kenya, No. 111, pp. 57.

Leakey, M.G., Leakey, R.E., 1978. Koobi Fora Research Project. The Fossil Hominids and An Introduction to their Context, 1968-1974, vol. 1. Clarendon Press, Oxford, pp. 191.

McDougall, I., Brown, F.H., 2006. Precise ${ }^{40} \mathrm{Ar} /{ }^{39} \mathrm{Ar}$ geochronology for the upper Koobi Fora Formation, Turkana Basin, northern
Kenya. Journal of the Geological Society, London 163, 205220.

McDougall, I., Brown, F.H., 2008. Geochronology of the pre-KBS Tuff sequence, Omo Group. Turkana Basin. Journal of the Geological Society, London 165, 549-562.

McDougall, I., Feibel, C.S., 1999. Numerical age control for the MiocenePliocene succession at Lothagam, a hominoid-bearing sequence in the northern Kenya Rift. Journal of the Geological Society, London 156, 731-745.

Murphy, M.A., Salvador, A. (Eds.), 1999. International stratigraphic guide - an abridged edition. Episodes 22, 255-271.

Nash, W.P., 1992. Analysis of oxygen with the electron microprobe: applications to hydrated glass and minerals. American Mineralogist $77,453-457$.

Ochieng', J.O., Wilkinson, A.F., Kagasi, J., Kimono, S., 1988. Geology of the Loiyangalani area. Report of the Mines and Geology Department, Kenya No. 107, pp. 53.

Owen, R.B., Renaut, R.W., 1986. Sedimentology, stratigraphy and paleoenvironments of the Holocene Galana Boi Formation, NE Lake Turkana, Kenya. In: Frostick, L.E., Renaut, R.W., Reid, I., Tiercelin, J.J. (Eds.), Sedimentation in the African Rifts. Geological Society Special Publication 25. Blackwell, Oxford, pp. 311-322.

Plaziat, J.C., Younis, W.R., 2005. The modern environments of molluscs in southern Mesopotamia, Iraq: a guide to paleogeographical reconstructions of Quaternary fluvial, palustrine and marine deposits.Carnets de Géologie/Notebooks on Geology, Brest, Article 2005/01 (CG2005_A01).

Rop, B., 1990. Stratigraphic and sedimentologic study of mesozoic strata in Loiyangalani Area, Lake Turkana District, North-West Kenya. Unpublished M.Sc. Thesis, University of Windsor, pp. 128.

Salvador, A. (Ed.), 1994. International Stratigraphic Guide - A Guide to Stratigraphic Classification Terminology and Procedure. Geological Society of America.

Savage, R.J.G., Williamson, P.G., 1978. Early rift sedimentation in the Turkana Basin, northern Kenya. In: Bishop, W.W. (Ed.), Geological Background to Fossil Man. Scottish Academic Press, Edinburgh, Scotland, pp. 375-394.

Steiger, R.H., Jäger, E., 1977. Subcommission on geochronology: convention on the use of decay constants in geo- and cosmochronology. Earth and Planetary Science Letters 36, 359-362.

Walter, R.O., Aronson, J.L., 1993. Age and source of the Sidi Hakoma Tuff, Hadar Formation, Ethiopia. Journal of Human Evolution 25, 229-240.

Watkins, R.T., 1983. The geology of the Suregei-Asille district and the upper Bakate Valley, northern Kenya. Unpublished Ph.D. Dissertation, Birkbeck College, University of London, London, pp. 390.

Wilkinson, A.F., 1988. Geology of the Allia Bay area. Report of the Mines and Geology Department, Kenya No. 109, pp. 54.

Wood, B., 1991. Koobi Fora Research Project, vol. 4. Clarendon Press, Oxford, England, pp. 466.

Yuretich, R.F., 1979. Modern sediments and sedimentary processes in Lake Rudolf (Lake Turkana) eastern Rift Valley, Kenya. Sedimentology 26, 313-331. 